\title{
Genesis and role of bitumen in fracture development during early catagenesis
}

Israa S. Abu-Mahfouz ${ }^{1 *}$, Joe Cartwright ${ }^{1}$ Erdem Idiz ${ }^{1}$, John N. Hooker ${ }^{2}$, Stuart Robinson ${ }^{1}$, Sander van den Boorn ${ }^{3}$

${ }^{1}$ University of Oxford, Department of Earth Sciences, South Parks Road, OX1 3AN Oxford, United Kingdom

2 Pennsylvania State University, Department of Geosciences, 503 Deike Bldg., University Park, 11Pennsylvania, USA

3 Shell Projects and Technology, Grasweg 31, 1031 HW Amsterdam, The Netherlands *Corresponding author (e-mail: isra.abumahfouz@spc.ox.ac.uk)

\section{ABSTRACT}

Bitumen-bearing fractures and vugs were investigated in the highly organic-rich Jordan Oil Shale (JOS) of Late Cretaceous to Eocene age, which has potential as a highly fractured, unconventional hydrocarbon play. Bitumen is present as macroscopically visible deposits and as inclusions in the cement of abundant natural fractures and adjacent vugs. The frequency of bitumen occurrence in fractures closely correlates with Total Organic Carbon (TOC) and burial depth. Petrographic and organicgeochemical analyses on bitumen samples extracted from fractures and their host rock matrix show that the fracture-filling bitumen comprises indigenous low maturity hydrocarbons derived from the surrounding organic-rich Oil Shale and has not migrated from a deeper source. Maturity indicators imply that the oil shale is in the pre-oil generation stage of early catagenesis throughout the investigated area, but with a regional increase in thermal maturity from west to east as the result of greater maximum burial depth. Bitumen mobilization in the host rock was mainly controlled by vertical loading stress acting on the non-Newtonian bitumen phase in load bearing configurations in the organic-rich matrix. Bitumen fractures were developed by hydraulic fracturing as the result of fluid overpressure in the organic matter. Overpressured bitumen has acted as a fracture driver, generating bitumen veins in both the organic-rich mudstones and the adjacent chert and silicified intervals. 
Keywords: Bitumen, Hydrocarbons, Biomarkers, Fractures, Jordan Oil Shale, Unconventional.

Natural fractures play an important role in hydrocarbon migration and accumulation (Nelson 1985; Mandl \& Harkness 1987; Jones et al. 1998; Aydin 2000; Childs et al. 2009; Wang et al. 2016). Hydrocarbons in the form of solid bitumen have been documented within fractures and pores in reservoirs and overlying seal rocks. These occurrences are present on a range of scales, including bitumen in large-scale structures such as Gilsonite dikes (Verbeek \& Grout 1983, 1992), in mineralized veins (Parnell et al. 2003, 2017a, 2017b; Fink 2016) and in microfractures (Ryder et al. 2013).

Most of the studies have focused on investigating bitumen occurrences that are hosted in stratigraphic units other than the source rock from which the bitumen was derived, and have used a variety of research methodologies including experimental work, field-based investigations and conceptual modelling (e.g., Parnell et al. 1991, 1994; Peters et al. 1996; Parnell \& Monson 1998; Wilhelms et al. 2001; Wang et al. 2015). There is, however, a paucity of studies that focus on solid bitumen formation and migration within the confines of the source rock interval, and as a result, there are many unresolved questions concerning this earliest phase of hydrocarbon mobilisation (Pepper 2017).

The prolific oil shale deposits of Late Cretaceous to Palaeogene age in Jordan provide an excellent opportunity to study the earliest stages of catagenesis, and in particular the factors leading to the formation of bitumen veins, and bitumen inclusions in mineralized veins. The oil shales are characterised as one of the richest oil shales in the world (Jaber et al., 1997; Hamarneh 1998; Dyni, 2006), and are widely developed in Jordan. They are identified both in outcrop and across a large area in the subsurface through drilling operations in the past 20 years. The oil shales have been studied previously for their organic matter enrichment, maturation, hydrocarbon potential and sedimentological and palaeo-environmental implications (Abed et al. 2005; Abed \& Arouri 1994; Abed et al. 2009; Ali Hussein et al. 2014a, 2014b; Hakimi et al. 2016, 2018; März et al. 2016). The organic geochemical characteristics of bitumen were only studied for bitumen present within the oil shale matrix (e.g., Abed 
et al. 2005; Hakimi et al. 2016). Fracture-filling bitumen present in these rocks has not been previously characterized for its thermal maturity and origin.

The scope of the present study is to examine the origin of the bitumen present within fractures and vugs and its relationships to fracturing in the Late Cretaceous-Eocene oil shale of Jordan. The study has three main aims:

(1) to define the source and emplacement history of the bitumen and test whether the bitumen is derived from a local source (i.e., JOS) or has migrated from a deeper petroleum source by studying its organicgeochemical characteristics;

(2) to better understand the transport mechanism of the bitumen into fractures and vugs; and

(3) to investigate whether bitumen maturation and migration coincide with fracturing, and if so, establish the nature of relationships between bitumen mobilisation and fracturing.

Recent studies of the natural fracture systems within the JOS have shown that diagenetic processes play an important role in fracture formation and distribution in the Cretaceous-Palaeogene strata of Jordan (Hooker et al. 2017; Huggett et al. 2017). Hooker et al. (2017) presented evidence of fracture formation controlled by silica diagenesis whereby fractures formed due to volume redistribution and loss associated with the opal-quartz transformation during early burial. Fractures were simultaneously filled by calcite. Their study demonstrated that chemical reactions can lead to open fracture pore space and that the created space can be filled by diagenetic mineral phases.

Bitumen is present within the oil shale matrix, natural fractures and adjacent vugs in the JOS, either in macroscopically visible deposits or as inclusions in the fracture cement. The geostatistical analysis of fracture distribution, petrographic investigation and geochemical analyses have been carried out on samples collected from 15 continuously cored sections through the JOS and selected outcrop localities. The studied cored wells and the outcrop are located in central and south Jordan (Fig. 1a). 


\section{The Jordan Oil Shale}

\section{Overview}

The JOS is an organic matter-rich, bituminous marl and limestone that was deposited in a highly reducing shallow marine environment during the Maastrichtian to Late Eocene (Abed \& Arouri 2006; Alnawafleh 2007; Alnawafleh \& Fraige 2015; Alqudah et al. 2015, März et al. 2016). Oil shale is considered as Jordan's most significant natural resource. Oil shale deposits underlie more than $60 \%$ of the Jordan territory, totalling $\sim 70$ billion tonnes. They are widespread in Jordan and can be recognized in few outcrops and mostly in the subsurface. Total organic carbon (TOC) ranges from 3 to 30wt\% (Hakimi et al. 2016). The organic matter has high oil generative capacities with Hydrogen Indices ranging between 600 and 900 and is characterised as a Type I/II-S kerogen due to its elevated Sulphur contents of between 2-12wt\% (Abed et al. 2005; Hakimi et al. 2016; Sokol et al. 2017; Al Aljariri Alhesan 2018).

\section{Geological Framework}

Jordan is located along the western border of the Arabian Plate. During the Cretaceous to Eocene period, the Arabian plate was part of the southern Neo-Tethys Ocean margin. The Neo-Tethys Sea periodically transgressed towards the south and east, onto the Arabian Craton (Powell \& Moh'd 2011). Marine conditions prevailed during the Cretaceous to Late Eocene and were terminated by uplift in the Latest Eocene (Fig. 1b). The area was then subjected to regional normal faulting, which was concentrated mainly along pre-existing faults and zones of weakness that were reactivated in a regime of $\mathrm{N} \_\mathrm{S}$ principal horizontal stress (Diabat \& Masri 2005).

The major tectonic features in central Jordan include the $\mathrm{N}-\mathrm{S}$ striking Dead Sea Graben/Rift valley to the West, a series of E-W striking, right-lateral strike-slip faults (e.g., Zarqa Ma'in and Suwaqa Faults), normal faults and grabens arranged in NW-SE direction (e.g., Azraq and Sirhan Grabens) and gentle folds belonging to the Syrian Arc (Al-Zoubi \& Ben-Avraham 2002; Diabat 2009; Segev et al. 2014). 
The Upper Cretaceous-Eocene succession is a passive continental margin sequence changing from carbonate platforms in south Jordan and open shelves in the central part to deep ramp and pelagic conditions in the North (Powell \& Moh'd 2011). The sedimentation and structure of Jordan were heavily influenced by tectonic evolution (Abu-Jaber et al. 1989; Alqudah et al. 2015). Major syn-sedimentary normal faults (NW—SE) considerably influenced the sedimentation of the JOS succession (Fig. 1c and 1d). The oil shale was deposited where restricted water circulation led to hypersalinity, reducing conditions, and enhanced organic matter preservation (Abed et al. 2005, März et al. 2016).

The study area in central and southern Jordan (Fig. 1a) is covered by a sedimentary succession ranging in age from the Late Cretaceous to the Eocene, which comprises three main geological formations (from older to younger): Al-Hisa Phosphorite (AHP), Muwaqqar Chalk Marl (MCM) and Umm Rijam ChertLimestone (URC) (Fig. 1b). The thickness of the MCM and the URC formations gradually decrease from north towards the south and southeast (Powell 1989). The three formations (AHP, MCM and URC) that host the JOS, and are the focus of the present study, are overlain by the Wadi Shallala Chalk Formation (WSC) and underlain by the Campanian Amman Silicified Limestone Formation (ASL) that together make up the Belqa Group (Abed 2000; Powell \& Moh'd 2011) (Fig. 1b). The Belqa Group spans the Cretaceous/Cenozoic boundary, which is marked by a depositional hiatus in the MCM (Yassini 1979) (Fig. 1b).

The AHP Formation (Maastrichtian) mainly comprises phosphorite, phosphoritic chert and limestone, chert, fossiliferous limestone (coquina) and bituminous marl. This formation contains abundant oysters, bivalves, fish and reptile fragments, and foraminifera, representing a shallow-water pelagic depositional environment (Powell \& Moh'd 2011).

The MCM Formation (Maastrichtian-Eocene) consists of interbedded bituminous marl (oil shale), phosphatic limestone, marly limestone and chert beds in the lower part, homogenous chalky and bituminous marl in the middle part and yellowish marl, chalky marl and black chert in the upper part. 
The phosphatic limestone, marly limestone and chert beds in the lowermost part of the MCM mark the top of the AHP.

The URC Formation, the uppermost formation of the studied section (Fig. 2a), is composed of alternating beds of chalky limestones, chalky marl, marly limestones, limestones, and abundant chert beds and nodules. The chalky marl and marly limestone beds are present in the lower part of the formation adjacent to the boundary with the underlying MCM formation. Carbonate concretions are abundant on the boundary with the MCM formation (Fig. 2a). Shell fragments, fish teeth and bones and microfossils, such as calcareous nanoplankton and foraminifera, are present in this formation. These litho- and bio-facies indicate a deep-water environment of deposition of the URC formation (Powell 1989; Powell \& Moh'd 2011; Alqudah et al. 2015). Both the URC and the underlying the MCM formation are thicker in the North of Jordan, and they gradually decrease in thicknesses towards the South and Southeast (Powell 1989).

\section{Lithostratigraphic Classification of the Studied Succession}

The cored intervals investigated in this study represent Upper Cretaceous through Eocene intervals of the Belqa Group including the AHP, the MCM and the URC Formations (Fig. 1b and 2b).

The outcrop locality included in this study is an open-pit oil shale quarry (El-Lajjun), situated about 100 $\mathrm{km}$ south of Amman. The El-Lajjun quarry mainly exposes the MCM and the lowermost part of the URC. The main structure in the El-Lajjun area is the El-Lajjun graben which controls a morphological depression bounded to the East and West by faults striking mostly $\mathrm{N}-\mathrm{S}$ (NRA 1990). The graben is approximately $10 \mathrm{~km}$ wide and $50 \mathrm{~m}$ thick. Syn-tectonic sediments were deposited in the graben during the Late Cretaceous-Early Palaeocene.

Because of the complex diachronous and repetitive nature of the oil shale interval (Alqudah et al. 2015) (Fig. 2c), the present study subdivides the cored intervals, into three main units (Lower, Middle and Upper) (Fig. 2a). The quarry section is equivalent to the most of the Middle Unit and a small part of the Upper Unit. The classification is mainly based on lithotypes and the presence (Lower and Upper units) 
or absence (Middle Unit) of chert beds/nodules as well as the enrichment of organic matter in the marl beds. This classification helped to construct a composite stratigraphic section from all cores and the equivalent parts in the outcrop.

Lower Unit: heterogeneous unit that is composed of phosphatic chalky marl, bituminous marl and phosphatic chert with carbonate and chert concretions. Chert beds and concretions occur along individual beds. They are typically $90 \%$ quartz and the remaining $10 \%$ is calcite (Huggett et al. 2017). Chert represents $15-20 \%$ of the rock volume of this unit. Bioturbation is moderate.

Middle Unit: homogenous interval that consists of organic-rich marl, with mainly calcite cement and microfossils cemented by calcite. Chert is very low within this unit. Bioturbation is high.

Upper Unit: this unit mainly composed of chalky limestone and chalky marls, with chert and silicified limestone beds and concretions. Bioturbation is intense.

Using this lithostratigraphic classification as a framework, fractures were measured and placed in a lithostratigraphic context (Fig. 2a-b).

It is worth to mention that the oil shales are buried to depths approaching $1000 \mathrm{~m}$ in the east of the country (Fig. 3), where regional tilting has led to present day burial close to or at maximum burial depth, whereas the western occurrences were affected by Neogene uplift and erosional unroofing, reflecting maximum burial depth shallower than of those in the East (Fig. 3).

\section{Methodology}

\section{Sample Selection and Description}

Bitumen was investigated within fractures, vugs and the matrix of host rocks in both core and outcrop. The fifteen examined cores include seven cores in the Harrana area, three in the Azraq area, two in the Sirhan area, and three in the Bayer area (Fig. 1a). The cored intervals range in length from $137 \mathrm{~m}$ to $293 \mathrm{~m}$ per well (see supplementary Table), with a core diameter of $10 \mathrm{~cm}$ The frequency, aperture and length of the bitumen-filled fractures were described and measured in each core. 
The quarry section provides an opportunity to analyse the horizontal distribution of bitumen fractures. Bitumen-bearing fractures and their spacings were measured along horizontal scan lines (Priest \& Hudson 1981; Priest 1993; Bons et al. 2004; Zeeb et al. 2013).

Thirty-eight representative samples were collected from core and outcrop (32 samples from the fifteen studied cores and 6 from the El-Lajjun exposure) and submitted for organic-geochemical and petrographic analyses. The samples were taken from both bitumen-bearing fractures and their host matrix. At least one fracture bitumen (FB) sample from each core was selected along with a matrix bitumen (MB) sample from the host organic-rich mudrock. If bitumen-bearing fractures occurred in chert or carbonate beds or concretions, matrix samples were taken from the adjacent mudstone beds (a few centimeters away from concretions). The average vertical distance between fracture and matrix bitumen samples is $\sim 2 \mathrm{~cm}$ (see supplementary data).

Thin sections with a thickness of $30 \mu \mathrm{m}$ were prepared from the fracture and matrix samples to study the bitumen present within the fractures and host rock. Optical analyses of thin sections of selected samples were made in cross-polarized light with a Nikon Optophot Microscope linked with a digital camera. The thin sections were also examined using a FEI Quanta 650 FEG scanning electron microscope (SEM). Backscattered electron (BSE) images were created to study mineral compositions and textures of the samples. Elemental mapping was performed using an energy-dispersive X-ray spectroscopy (EDS) attachment to the SEM. All SEM analyses were performed at $20 \mathrm{kV}$ and a working distance of about $10 \mathrm{~mm}$.

\section{Organic Geochemistry}

\section{Methods:}

Geochemical analyses of the JOS, including Total Organic Carbon (TOC) and Total Sulphur (TS), were performed using a LECO elemental analyser. Rock Eval pyrolysis was used to characterize the type and maturity of the organic matter using a Vinci Rock-Eval 6 Analyser. 
Twenty-four samples (22 from cores and 2 from the exposure) were selected for extract analyses. Rock samples were prepared by rinsing with distilled water and dichloromethane (DCM). The bitumen was extracted from samples drilled out of fractures/vugs and rock matrix using a standard Soxhlet Extraction technique (Mueller \& Philp 1998). Briefly, pulverized and weighed samples were loaded into Soxhlet extractors containing a 3:1 mixture of DCM and Methanol $\left(\mathrm{CH}_{3} \mathrm{OH}\right.$; abbreviated here $\left.\mathrm{MeOH}\right)$ and extracted for $24 \mathrm{hrs}$, then blown down under $\mathrm{N}_{2}$ gas. Asphaltenes, which represent a substantial fraction of the extract, were precipitated from the whole extract using an excess of hexane (Aske et al. 2001). The samples were then centrifuged at $5000 \mathrm{rpm}$, and the supernatant solution of each sample, representing the maltene fraction, was carefully transferred into a separate glass vial and blown down to about $0.5 \mathrm{ml}$ by $\mathrm{N}_{2}$ gas. Elemental Sulphur was removed using activated copper prior to column chromatography.

The extracts were passed through a column containing silica gel to remove any remaining water, before being separated by alumina $\left(\mathrm{Al}_{2} \mathrm{O}_{3}\right)$ column chromatography. The extract sample was eluted sequentially by hexane/DCM $(9: 1, \mathrm{v} / \mathrm{v})$ and DCM/MeOH $(1: 1, \mathrm{v} / \mathrm{v})$ to separate aliphatic and aromatic fractions respectively.

Biomarkers from the maltene fraction were analysed using an Agilent 5977B GCMS. The GC oven program was set to $80{ }^{\circ} \mathrm{C}$ for $1 \mathrm{~min}$, then increased to $130{ }^{\circ} \mathrm{C}$ at $20^{\circ} \mathrm{C} / \mathrm{min}$, and then to a maximum temperature of $325^{\circ} \mathrm{C}$ at $10{ }^{\circ} \mathrm{C} / \mathrm{min}$ where is was held for $30 \mathrm{~min}$. Triterpane and sterane biomarkers were identified from the maltene fraction with the standard methods using $\mathrm{m} / \mathrm{z} 191$ and $\mathrm{m} / \mathrm{z} 217$ fragmentograms run in SIM mode. The biomarker results were compared to an internal standard (SRM2266). Identification of biomarkers was carried out based on the retention time.

\section{Results}

\section{Fracture Description}

\section{Fracture Types and Mineralization}

A wide range of structures were observed and measured from the core and outcrop. These include veins (cemented fractures), joints (uncemented fractures), cone-in-cone structures, faults (fractures with 
offsets), and dilatational breccias. Cemented veins include both mineralized and bitumen-filled veins. Opening-mode fractures (veins and joints) are the most dominant fracture type observed in the core and outcrop (Fig. 4a). Shear fractures are counted as faults.

At the core scale, veins are the most abundant fracture type observed (Fig. 4a). They are identified by the distinct colors of their filling materials. They are sealed by different types of cements including calcite, silica (as quartz or chalcedony), and bitumen. Most of the opening-mode fractures observed in the core are planar; however, a considerable number are folded (compacted) veins (Fig. 4b). These folded veins are filled by calcite and are interpreted by Hooker et al. (2017) to be deformed by sediment compaction after early emplacement.

Bitumen is either present within the mineralized veins, or entirely fills fractures and vugs. Fractures entirely filled by bitumen are referred to here as bitumen veins (BVs) (Fig. 5b and 5d-g). Bitumen is only found within the planar veins; no observations were documented of bitumen within folded calcite veins (FCVs). Bitumen in unfolded calcite veins (BCVs) is observed either as solid inclusions within the cement or as fillings of the remaining porosity and inter-crystalline pore space (Fig. 5a and 5c). No crosscutting relationships between calcite veins and bitumen veins were documented.

Neither is bitumen found in silica-cemented veins (SVs), but BVs are observed to crosscut SVs (Fig $5 f$ and $6 \mathrm{a}-\mathrm{b}$, and some BVs exploit the preexisting SVs by running immediately adjacent and parallel to SVs (BSVs) (Fig. 6a-b). These observations establish that the timing of BVs post-dates the SVs.

There are many examples in the cores of horizontal BCVs crosscutting early folded calcite veins (Fig. 6f-g), but BCVs and BVs have not been observed crosscutting each other. Importantly, no systematic crosscutting relationships are observed between horizontal BVs and vertical BVs. This suggests that all geometries and types of bitumen-bearing fractures are coeval.

There are only a few observations of bitumen inclusions associated with shear fractures (faults), such as observed in the lower unit of core 7 at a depth of $667 \mathrm{~m}$. These few cases mainly represent bitumen that occurs within the fault cement or in opening-mode fractures that are associated with fault damage zones. 
Fractured beds are predominantly those cemented by carbonate and silicate minerals (Huggett et al.,

247 2017). Fracture cements generally reflect the lithology of the host unit such that calcite veins are 248 observed in calcareous mudstones and limestones whereas chalcedony and silica veins are present in 249 silicified/chert beds.

250 In the quarry section, only BVs are observed, and they are confined to the oil shale beds. No mineralized 251 veins containing any form of bitumen were observed in the quarry (i.e., no BSVs, BCVs).

\section{Fracture Orientation, Geometry and Aperture}

253 The majority $(>70 \%)$ of the bitumen-bearing fractures (BVs and BCVs) observed in the cores are sub254 vertical to vertical (Fig. 5a-c and 6c-d). The dip angles of most vertical bitumen-bearing fractures 255 observed in the core vary with the change in lithology chert and carbonates beds/concretions (Fig. 5a, 256 $5 \mathrm{~d}$ and 6e). Due to the unknown orientation of the core, the true fracture strike was not constrained in this study. Horizontal fractures (bedding-parallel) and a combination of horizontal and vertical fractures forming complex fracture networks also occur (Fig. $5 f$ and $6 f-g)$.

Vertical bitumen-bearing fractures in the cores range from 1 to $120 \mathrm{~cm}$ in height (parallel to the core axis), whereas the length of bed-parallel fractures (orthogonal to core axis) is not measurable due to the limited core width. Vertical core fractures measured within the homogenous organic-rich marl unit (Middle Unit), have smaller apertures and greater heights than fractures within the heterogeneous units (Lower and Upper units), which are commonly restricted vertically by chert and silicified bands. BVs cut across their host beds or concretions entirely (Fig. 5b, 5d-g and 6a-e).

BVs are less strictly planar (more irregular) than other mineralized veins (i.e., CVs and CVs) and bitumen-bearing fractures (i.e., BSVs and BCVs) (Fig. 5d-g and 6d-e). Bitumen-bearing fractures show a range of tip morphologies varying from single tapering ends to branching ends (Fig. 5 and 6). Individual thick BVs commonly branch, particularly within mudstone beds (Fig. 6e). BVs tend to have larger apertures in the chert, silicified and carbonate beds or concretions than in the mudstone (Fig. 5d- 
f, and 6d-e). Both BCVs and BVs tend to deflect in their trajectory when crossing different lithofacies

271

272

273

274 (Fig. 5a, 5d, and 6e).

Generally, BVs have larger aperture sizes than other bitumen-bearing fractures (Fig. 6d-e). The maximum aperture size of BVs averages $0.90 \mathrm{~cm}$ while it averages $0.40 \mathrm{~cm}$ for BCVs. BVs display apertures that are variable along fracture traces (Fig. 6d-e). In all types of bitumen-bearing fractures, fracture aperture decreases in a fairly regular taper towards the tips (Fig. 5a-g and 6a-c).

BVs observed in the El-Lajjun quarry are planar and exclusively vertical (Fig. 6c). They range in height from $5 \mathrm{~cm}$ to $20 \mathrm{~cm}$ and have a mean maximum aperture of $0.20 \mathrm{~cm}$. The veins in outcrop do not exhibit any branching features that are comparable to the BVs observed in the cores.

\section{Fracture Intensity and Distribution}

Bitumen-bearing fractures are found dominantly in the lower section of in all cores, which comprises organic-rich mudstones interbedded with silicified units or chert beds/nodules (Fig. 2). The majority of bitumen-bearing fractures in the lower unit are confined to silicified, chert and carbonate beds/concretions positioned between un-fractured, organic-rich mudstone beds particularly those mudstone beds with higher contents of TOC and S (Fig. 2b; Table 1).

Generally, BVs are highly interconnected in the core; it is difficult to find individual BVs that do not intersect others (Fig. 5d, 5f and 6e). Other bitumen-bearing fractures are commonly observed as singular fractures (Fig. 5a, 5c and 6d). Both horizontal and vertical bitumen-bearing fractures are observed within the Lower Unit; however, horizontal fractures are less abundant than vertical fractures and $90 \%$ of them are only filled by bitumen (as BVs).

BVs are closely spaced in the core and tend to cluster. This clustering increases the chance of observing them within the limited core width and may explain the high intensity of BVs compared to other bitumen-bearing fractures that might have a wider fracture spacing that exceeds the core width.

The frequencies and cumulative lengths of all bitumen-bearing fractures were normalized to the length of recovered core (Fig. 2). The data reflect high intensities of bitumen-filled fractures and vugs with the 
progressive increase of the present-day depth (Fig. 2 and 3a-b). A few BVs (5\% of total bitumen fractures) are observed in the middle unit in the homogenous organic-rich mudstones that lack chert.

Bitumen-bearing fractures are more abundant in the Azraq cores (CE Jordan) than the Harrana cores (CW Jordan) (Fig. 3a-b). This increase in abundance eastwards may reflect the greater maximum burial depth (Fig. 3b). The intensity of bitumen fractures in in the lower unit of the core in the East is more than double the intensity in the same unit in the West.

Bitumen fractures are also observed in the outcrop at the El-Lajjun quarry within the lower part of the MCM formation confined to a $20-\mathrm{cm}$ thick organic-rich oil shale bed (Fig. 6c). The quarry allowed a 3D visualization of bitumen-bearing fractures and their horizontal distribution. The fractures heights are mostly equal to the bed thickness. The average fracture spacing of the measured fractures is $12 \mathrm{~cm}$.

\section{Petrographic Description of Host Rock and Bitumen-Bearing Fractures}

Petrographic examination revealed a wide variety of host rock lithologies, fracture cements, textures and crosscutting relationships. This demonstrates a complex history of deposition, fracturing and sealing. It also allowed characterisation of the microscopic occurrences of bitumen and its migration pathways.

Petrographic investigation of both the lower unit, which is the host of most of the bitumen-bearing fractures, and the middle unit shows that the mudstone mainly consists of calcite, quartz, organic matter (bitumen) and apatite, with locally considerable amounts of chalcedony, dolomite, and occasionally pyrite (Huggett et al. 2017). Clay is only rarely observed and quartz is commonly of microcrystalline nature. Calcite has cemented most microfossils and radiolaria are locally abundant.

The interbedding of chert and mudstone in the lower unit is believed to be the result of diagenetic alteration of locally abundant concentrations of radiolaria and diatoms (Hooker et al. 2017). The chert is believed to have developed by replacing carbonate components in the original host material with silica from biogenic components (Hooker et al. 2017; Huggett et al. 2017). This is consistent with the low silica content of the adjacent mudstones. 
Bitumen is observed as small amorphous particles in variable shapes and as flakes that are present in the matrix of the organic-rich mudstones (oil shale) in both the lower and middle units (Fig. 7c-d).

Fracture bitumen under the microscope is observed to either entirely fill the fracture (i.e., bitumen in BVs; Fig. 7c and 7f), or to be texturally enclosed by calcite cements (i.e., in BCVs; Fig. 7a). BCVs are characterized by a crack-seal texture (e.g., Ramsay 1980), represented by multiple generations of calcite crystals with elongate-blocky morphology (Fig. 7a). The veins appear under the microscope as multiple parallel bands of cements. The crack-seal texture indicates that calcite precipitation was synchronous with fracture opening. Micro-bitumen inclusions (sub-millimetre-scale) and inclusions of organic-rich host-rock are present within the cement of these calcite veins (Fig. 7a-b) which indicates that bitumen was present during formation of the veins. Bitumen filling the vacant segments of partiallyfilled BCVs appears to have similar petrographic properties to the bitumen within the calcite cement.

Bitumen micro-veins (BMVs) are observed in internally branching networks, resulting in incipient brecciation of the organic-rich mudstone (Fig. 5g, and 7f-g). Horizontal and sub-horizontal microfractures entirely filled by bitumen are also commonly observed within the organic-rich mudstone (Fig. 7c). This microfracturing is observed particularly around or at the margin of calcite and pyrite crystals (Fig. 7c-d).

Microscopic examination of FCV shows that these early veins do not contain any traces of bitumen but are entirely cemented by calcite. This indicates that bitumen generation and migration postdate the development of folded veins. It also strongly supports the macroscopic observations described above from the core.

BVs exhibit a clear crosscutting relationship with SVs at the microscale but not with BCVs. Importantly, the silica cement in SVs is entirely free of bitumen inclusions. BMVs with varied directions were observed, including vertical BMVs, horizontal BMVs and network BMVs. However, no crosscutting relationships between horizontal and vertical BMVs were detected. 


\section{Organic Geochemistry}

\section{Source Rock Characterization}

Geochemical properties of the JOS samples are presented in Table 2. The JOS has high TOC values ranging from 6 to $30 \mathrm{wt} \%$ and $\mathrm{S}$ contents from 1.5 to $8.3 \mathrm{wt} \%$. Hydrogen Index (HI) values range from 583 to $880 \mathrm{mg} \mathrm{HC} / \mathrm{g}$ TOC, indicating excellent oil-prone kerogen. The Tmax values range from 389 to $424{ }^{\circ} \mathrm{C}(<0.6 \% \mathrm{VR} / \mathrm{E})$, and the Production Index (PI) has an average of about $0.03 \mathrm{mg} / \mathrm{g}$ TOC, both parameters indicating a thermally immature source rock (Fig. 8). The low maturity of the JOS indicates that regional maximum palaeo-burial depths were likely shallow (few hundred metres), or more accurately, palaeo-burial temperatures were low $\left(\sim 30-50^{\circ} \mathrm{C}\right)$.

\section{Biomarkers of Fracture and Matrix Bitumens}

Table 3 lists pertinent characteristics of the $\mathrm{m} / \mathrm{z} 191$ (Triterpenoids) and 217 fragmentograms (Steranes) from extracts of both fracture (FB) and matrix bitumen (MB). The most prominent feature of the triterpane fragmentogram is the high concentration of gammacerane (Fig. 9a-b), which is an indicator of water column stratification possibly due to salinity variations (Mello et al. 1988; Sinninghe-Damste et al. 1995, Peters et al. 2005). C29:C30 $\alpha \beta$ hopane ratios range from 0.27-0.60 and gammacerane: C30 $\alpha \beta$ hopane ratios from $0.34-0.93$. The $22 \mathrm{~S} /(22 \mathrm{~S}+\mathrm{R}) \mathrm{C}_{31} \alpha \beta$ extended-hopane ratio ranges from very immature values of 0.2 to the equilibrium value of 0.6 (Peters et al. 2005).

Sterane biomarkers are commonly used to indicate depositional environments and organic matter biomass input (Huang \& Meinschein 1979; Seifert \& Moldowan 1981; Volkman 1986; Peters et al.

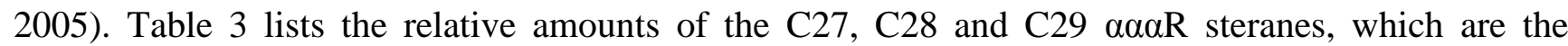
predominant isomers in all the samples. The samples all show a predominance of C27 steranes (4758\%), with subequal amounts of $\mathrm{C} 28$ and $\mathrm{C} 29$ steranes comprising the rest (Fig. 9c-d, and 10). All the samples, both matrix and bitumen, cluster in a relatively small area in Fig. 10, indicating very similar biomass contributions to the kerogen of the JOS (Huang \& Meinschein 1979; Seifert \& Moldowan 1981; Volkman 1986; Peters et al. 2005). 
$20 \mathrm{~S} /(20 \mathrm{~S}+20 \mathrm{R}) \alpha \alpha \alpha$ and the $\alpha \beta \beta /(\alpha \beta \beta+\alpha \alpha \alpha) \mathrm{C} 28$ sterane ratios range from $0.25-0.52$ and $0.41-0.66$ respectively set (Table 3; Fig. 11a). Most of the samples have yet to reach the equilibrium maturity values for these maturity parameters of 0.55 and 0.7 , respectively, and attest to their low maturity.

\section{Discussion}

\section{Source and Maturity of Fracture Bitumens}

The JOS bituminous and organic rich marls comprise an excellent oil prone source rock. The presence of Type I/II-S kerogens indicates high quality organic matter type that is able to generate low API gravity, asphaltene-rich bitumen at relatively low thermal stress because of the high sulphur (1.512wt\%) contents (Burnham 2017).

The biomarker data obtained from the matrix and fracture bitumens from the JOS indicate that they are sourced from the same type of organic matter. Subtle variations in biomarker parameters (e.g., C29/C30 hopane, gammacerane/hopane and the sterane carbon number distributions) between wells probably reflect slight geographic differences in environment of deposition and biomass input. Although a detailed discussion of the formation of these source rocks is beyond the scope of this paper, the pertinent point is that there is a close similarity in the biomarker patterns of the matrix bitumen, and the solid bitumen found in fractures and vugs (Fig. 9 and 11). Most compelling are the maturity-related hopane and sterane isomerization parameters (e.g., hopane 22S/(22S+22R), and sterane 20S/20S-20R) and $\alpha \beta \beta /(\alpha \beta \beta+\alpha \alpha \alpha)$ parameters) that are remarkably similar between matrix and fracture bitumen and indicate low thermal levels of stress, which is also consistent with bulk Tmax values that point to low thermal maturity $(0.5-0.6 \% \mathrm{VRE})$. These lines of evidence strongly suggest that both matrix and fracture bitumen is locally derived and indigenous to the JOS and has migrated at most on the scale of a few beds, i.e., cm-scale to m-scale migration. This applies to both fractures and vugs hosted in the bituminous marls and to those that extend into adjacent chert and carbonate beds which inherently have little or no organic matter. 
Samples from Core 6 and the quarry show the lowest levels of maturity for the matrix and fracture/vug bitumens (Fig. 11a), suggesting the least amount of burial/thermal stress for these localities. This is consistent with their shallow present day burial depth, and likely minimum maximum burial depth relative to their counterparts in the eastern part of the basin (Fig. 3).

\section{Bitumen Generation and Migration}

The elevated TOC and sulphur contents of the JOS are considered here to be the prime factor in the relatively early mobilisation of a bitumen phase. Although the JOS is immature by conventional standards of thermal maturity, the high total content of sulphur up to $8 \mathrm{wt} \%$ analysed in the present study (Table1) and up to $12 \mathrm{wt} \%$ in other studies (e.g., Al Aljariri Alhesan 2018), is interpreted to have contributed to early cracking of the Type I/II-S kerogen, resulting in the generation of bitumen (Burnham 2017).

Hydrocarbon migration out of the source rock is usually considered as the explanation for the presence of solid bitumen in veins (Parnell \& Carey 1995; Fink et al. 2016). In the case of the JOS, the presence of solid bitumen within matrix, fractures and vugs within the main source interval is attributed to very short distance (mm- to m-scale) hydrocarbon migration through fractures and vugs.

The early-generated bitumen appears to have been squeezed out and mobilised not by buoyancy forces (as with some views of primary hydrocarbon migration), but under the vertical load imposed during peak burial. Following the recent model of Pepper (2017), it is suggested that the transformation from the kerogen to the bitumen phase generated an overpressure (i.e., by fluid volume increase) that was equivalent to the overburden stress and enabled the bitumen to migrate via newly propagating fracture pathways through the host organic-rich mudstone beds. This process is different from the conventional notion of primary migration where hydrocarbons saturate available pore spaces before being expelled into carrier beds. Instead, these rocks have extruded early-generated heavy bitumen under the overburden load and led to redistribution into vugs and pre-existing (BCVs) or newly-forming fractures. 
The presence of early-generated bitumen in the pores of the low-permeability mudrocks has built up overpressure that triggered new fractures $(\mathrm{BVs})$ to create.

The difference in physical and mechanical rock properties of the chert, carbonate and mudstone beds in the host source rock interval can be viewed as a form of mechanical stratigraphy (cf. Gross 1995). This interbedding of contrasting rock types may have exerted a second order control on the bitumen migration in that local stress concentrations (e.g., around chert and carbonate nodules) may have promoted fracturing at bed boundaries that could be exploited by the mobilised bitumen. It is also likely that the overpressure within the bitumen phase was instrumental in driving fracture propagation, as indeed implied by the prevalence of both vertical and horizontal bitumen veins (cf. Mandl \& Harkness 1987). Following expulsion of bitumen by mechanical compaction when the load-bearing capacity of the source rocks was exceeded, the resulting volume decrease of the rocks caused overpressure that allowed the bitumen to migrate only short (cm-scale) distances from the saturated mudstone (oil shale) beds towards the adjacent silicified, chert and carbonate beds or concretions via networks of newly propagating bitumen-bearing fractures (Fig. 6d-f and 12). This situation is considered as a good indication of bitumen expulsion resulting from mechanical compaction once the bitumen phase achieved load bearing capacity and is seen, for example, through a low-organic content mudstone zone on the contact with the chert or carbonate beds/concretions (see Fig. 5b and 5e). It indicates that the compaction-related pressure has allowed the migration of the low-maturity bitumen generated from the local kerogen and squeezed it, creating fractures (Fig. 12).

Furthermore, the strongly comparable geochemical signatures of the fracture and matrix bitumen are a robust indication of local migration (cm-scale) of bitumen from the saturated mudstone (organic-rich oil shale) towards the brittle chert and carbonate intervals (Fig. 8, 10 and 11). Petrographic observations (Fig. 7f) show that the direction of fracture propagation is from the organic-rich mudstone beds towards the chert or carbonate concretions. The pathways taken by migrating bitumen from outside carbonate concretions directed inward to their interiors is also evident in microscopic observations (Fig. 7f). 


\section{Development of Bitumen-bearing Fractures}

\section{Distribution of Bitumen-Bearing Fractures}

The vertical distribution of bitumen-bearing fractures in the cores is influenced by two main factors. In the lower unit of all cored successions, the fracture intensity shows a positive correlation with TOC and TS (Fig. 2c). This observation is consistent with the model presented in the previous section for local bitumen generation and mobilisation during early catagenesis since the fracture intensity would be expected to be greatest where the concentration of kerogen is highest. It is interesting to observe that fracture intensity also correlates with TS, which is consistent with the arguments presented above that it is the high sulphur contents that allows very early bitumen generation.

The second factor is the gross burial history and thermal stress that the source interval experienced. The high intensity of bitumen-bearing fractures in the lower unit of the cores when compared to the overlying two units (middle and upper units) indicates that burial depth plays a role in the development of these fractures. The overall increase in fracture intensity of the lower fractured interval from West to East (Fig. 3a-b) is another indicator that increased maximum burial in the East and enhanced thermal stress and peak temperatures play a role in fracture formation.

At the bed scale, bitumen-bearing fractures are mainly observed clustering in the chert and silicified beds, positioned between or beneath organic-rich beds in the lower unit. This predominance of bitumenbearing fractures in layers with high rock stiffness indicates that the development of bitumen fractures has been primarily controlled by the physical and mechanical properties of the rock, represented by the small-scale mechanical stratigraphy. Rapid vertical changes in Poisson's ratio have been suggested as a means for localising mode 1 fracture development (Teufel \& Clark 1984; McDermott et al. 2013), and such a mechanism could apply here.

Fracture analysis of the outcrop analogue provided some constraints on possible horizontal distribution of BVs in the middle unit, which in the core has very low fracture abundance. The average fracture spacing at outcrop was c. $12 \mathrm{~cm}$ which is almost double the typical core diameter, and thus facture 
intensity in the middle unit from core observation is certainly significantly underestimated (cf. Alfahmi 2018).

\section{Timing of Bitumen-Bearing Fractures}

Cross-cutting relations are critical for constraining the timing of fractures (Beaudoin et al. 2015; Hooker et al. 2018). The lack of systematic cross-cutting relationships between the different types of bitumenbearing fractures leads to the conclusion that these fractures were developing coevally during the period of active bitumen generation. BCVs and BVs seem to have crosscut all other type of fractures except for late calcite veins; suggesting that BCVs and BVs postdate all opening-mode fractures (i.e., SVs and FCVs) present in the studied succession and are coeval with late calcite veins (Fig. 6c and 6f-g). The crosscutting relationship between vertical BVs and SVs indicates that both the BCVs and BVs postdate silica diagenesis. The absence of any crosscutting relationships between vertical and horizontal BVs in the core and at the microscale implies a synchroneity in the development of both the horizontal and vertical $\mathrm{BVs}$, and this in turn points to the development of a lithostatic overpressure in the bitumen phase (cf. Mandl \& Harkness 1987).

At the microscale, the presence of bitumen inclusions within the cement of the planar calcite veins (i.e., BCVs), indicates that bitumen was present during the opening and sealing of the vein. This suggests that bitumen migration coincides with the formation of calcite veins. The crack-seal pattern of BCVs further indicates that calcite precipitation was synchronous with opening of the fracture. Similar arguments were advanced for the co-existence of bitumen and saturated mineralising pore fluids by Parnell and Carey (1995).

The late development of bitumen-bearing fractures (cf. Hooker et al. 2017) is consistent with the model presented above for bitumen mobilisation at the peak of thermal stress, i.e., at a late stage in the burial history prior to any uplift and cooling. 


\section{Formation Mechanisms of Bitumen-Bearing Fractures}

Generally, opening-mode fractures propagate along a plane perpendicular to the minimum-compressive principal stress, normal to the plane of the crack (Secor 1965). One mechanism for their formation is hydraulic fracturing, where a pore pressure exceeds the least compressive total normal stress, but they may also form at pore pressures significantly less than the overburden stress and by minor extensional or volumetric strains, or thermal stresses, particularly under shallow burial conditions (Eichhubl et al. 2001; Eichhubl \& Aydin 2003; Olson et al. 2009).

Veins are considered as important structural elements since they reflect stages of geological activity that occurred after formation of the host unit (Bons et al. 2012). According to Hooker et al. (2017), calcite cement in the different types of calcite veins present in the JOS has been formed at many different phases during both burial and uplift of the host units. The high percentage of calcite veins in the calcareous, organic-rich oil shale relative to all opening-mode fractures suggests the circulation of calcium carbonate-rich fluids in the fracture networks.

Calcite veins are considered here to be formed by three possible fracture-forming mechanisms. These include diagenetic processes, tectonic stresses or fluid overpressure. The investigated bitumen-bearing fractures are coeval with late planar calcite veins which are believed to be tectonic-related fractures (Hooker et al., 2017). The BCVs identified in the present study have elongate-blocky textures which reveal a moderate crack opening rate according to Prajapati et al. (2018). Elongate-blocky crystals demonstrate preferred orientations at the final phase of growth, indicating the presence of growth competition during vein development (Hilgers \& Urai 2002; Prajapati et al. 2018).

The sealing of BCVs shows overlapping filling stages. This is evidenced by the occurrence of bitumen within the crack-seal structure which suggests that the bitumen occurrence is syngenetic with the cementation of calcite veins (see Fig. 7a-b) (cf. Parnell \& Carey 1995). The crack-seal texture implies incremental opening and sealing. This internal structure of these veins indicates that the calcite has started to precipitate in the fracture, and the bitumen filled the remaining porosity and the vacant 
segments before the fractures were entirely sealed. A process similar to this was proposed in a study of the Woodford Shale by Comer (2007).

The folded calcite veins are free of any bitumen traces and are thought to have formed during early burial in response to silica diagenesis and were folded by sediment compaction (Hooker et al. 2017). Planar SVs are also thought to have formed early due to silica diagenesis. The sequence of events of all these fractures cements is summarized in Fig. 13 (Hooker et al. 2017).

Low permeability and high organic content play a key role in fracturing (Mandl \& Harkness 1987). The development of bitumen-bearing fractures appears to have been controlled (for BVs) or at least have been assisted (for BVCs) by hydraulic fracturing, driven by lithostatic fluid overpressure in the organic material. Brecciation in the organic-rich mudstone, particularly mosaic brecciation (see Fig. 5g, and $5 \mathrm{~g}$ ), can be indicative of hydraulically-fractured rock due to fluid overpressure within this lowpermeability unit (Parnell \& Carey 1995; Passchier 2000). The bitumen-supported breccia in the mudstone reflects a pressure regime that has been hydrostatic and then developed to highly elevated overpressured led to fracture (i.e., brecciation) the host mudstone (Parnell \& Carey 1995).

The bed-parallel BVs and BVCs present within the organic-rich oil shale (see Fig. 6c and 6f-g) show a good example of hydraulic-fracturing produced by bitumen overpressuring in which the bitumen pore pressure exceeds the vertical stress generated by the overburden load. The hydraulic fracture usually occurs when the Mohr circle touches the failure envelope. The size of Mohr circle is governed by effective stress $\left(\sigma^{-}\right)$, which is represented by the difference between total stress $(\sigma)$ and fluid pressure $(\boldsymbol{p F})$ :

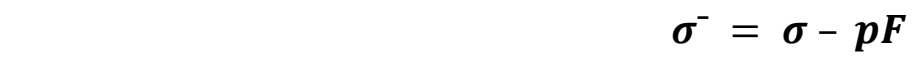

At the microscopic scale, the development of bitumen filaments in well-developed microfractures (BMVs) within the organic-rich mudstone beds also indicates fracturing due to high pore pressure (Fig. 7c). These BMVs that propagate within and around calcite and pyrite crystals, are interpreted to 
have been generated by fluid pressure in the bitumen phase $(\boldsymbol{p} \boldsymbol{B})$ that exceeded the vertical stress $(\boldsymbol{\sigma} \boldsymbol{v})$ :

$$
p B>\sigma v
$$

Fracturing driven by fluid overpressure relating to maturation of organic matter has been documented in a range of studies (e.g., Jochum et al. 1995; Zhang et al. 2016; Meng et al. 2017). It is often suggested that volume expansion of kerogen during thermal maturation is the main driver for fracturing (Michels et al. 1994; Figueroa Pilz et al. 2017). In the case of the JOS, the generated bitumen is of early maturity. However, the yield of this early expelled bitumen seems to have been high enough to cause a volume change that resulted in fracturing.

The stiffness of chert and silicified beds is argued to have directed the fracturing to be straighter and with bigger apertures than in the ductile mudstone; emphasising the role of the rock properties in fracturing and aperture development.

The aperture irregularity of BVs in silicified and chert beds (Fig. 6d-e), the deflection of veins when they propagate in different beds (Fig. 5a, and 6e) and the branching and splaying of BVs in mudstone (Fig. 6e) all indicate that the fracturing generated by fluid overpressure was controlled by the rock properties (Bons et al. 2012). The veins seem to have been able to branch or change direction due to the ductility of the mud rocks, presenting further evidence of fracture formation due to fluid overpressure. Therefore, we argue that in the low-permeability mudstone beds, the bitumen overpressure has forced the mudstone to fracture or brecciate. This is consistent with the study of Parnell \& Carey (1995).

A final line of evidence for overpressured bitumen acting as a fracture driver comes from the observation that a single BV can propagate through three types (mudstone, chert and carbonate) of rocks with different mechanical properties (Fig. 5d). This is also supported by microscopic observations where BVs and MBVs propagate from an organic-rich mudstone bed towards a carbonate concretion (see Fig. 7f).

The microscopic occurrence of bitumen within the matrix in both the lower and middle units of the core indicates that the bitumen has been subjected to an external pressure that forced this in-situ bitumen to find a way to release this pressure by generating fractures in the low permeability mudstone matrix. 


\section{Conclusions}

(1) The biomarker and petrographic results of fracture and matrix bitumen from 15 cores and one outcrop of the JOS show that the source of bitumen within fractures and adjacent vugs are very low-mature hydrocarbons expelled from the JOS matrix, and have not migrated from another petroleum source.

(2) Maturity indicators imply that the oil shale is everywhere in the very early-oil generation stage, but with a regional variation from west to east resulting from greater maximum burial depth.

(3) The present study has revealed that bitumen fractures developed by hydraulic fracturing as the result of fluid overpressure in the organic matter due to permeability destruction in the organic mudstones which prevents fluid loss. Overpressured bitumen has acted as a fracture driver, generating bitumen veins in both the organic-rich mudstones and the adjacent chert and silicified intervals.

(4) Rock properties played an important role in the distribution of bitumen-bearing fractures with High intensities of bitumen-bearing fractures occurring in chert and silicified beds.

(5) Late calcite veins contain bitumen inclusion (BCVs) which shows that bitumen occurrence is syngenetic with the cementation of calcite veins, and was generated relatively late in the paragenetic sequence.

\section{Acknowledgment}

This research is a part of a $\mathrm{PhD}$ project being conducted by Israa $\mathrm{S}$. Abu-Mahfouz as a part of the "Fractures in Mudrocks" theme under the Shell-Oxford collaborative agreement. We thank the Jordan oil shale company (JOSCO) for providing the core data and samples. We thank Lauren O'Connor, Alexander Dickson, Jon Wells, and Stephen Wyatt for helping with the laboratory preparations.

\section{Funding}

This research is co-funded by Royal Dutch Shell PLC, represented by JOSCO, and the University of Oxford. 


\section{References}

Abed, A.M., 2000. The Geology of Jordan and Its Environment and Water (in Arabic). Publication of the Jordanian Geologists Association, Amman

Abed, A.M., \& Al-Arouri, K. 1994. Organic Geochemistry of Central Jordan Upper Cretaceous Phosphorites: Phosphogenesis and Source Rock. Proceedings of the 2nd International Conference-Geology of the Arab World, Cairo University, Cairo, 321-338

Abed, A.M., Arouri, K.R. \& Boreham, C.J. 2005. Source rock potential of the phosphorite bituminous chalkmarl sequence in Jordan, Mar. Pet. Geol., v. 22. p. 413-425

Abed, A.M. \& Arouri, K. 2006. Characterization and Genesis of Oil Shale from Jordan. International

Conference on Oils Shale, University of Jordan, Amman, Jordan

Abed, A.M., Arouri, K., Amiereh, B.S. \& Al-Hawari, Z. 2009. Characterization and Genesis of Some Jordanian Oil Shales. Dirasat. Pure Sciences, v. 36, p. 7-17

Abu-Jaber, N.S. Kimberly, M.M. \& Cavaroc, V.V. 1989. Mesozoic-Paleogene basin development within the eastern Mediterranean borderland: J. Pet. Geol., v. 12, p. 419-436

Al-Bahlani, A.M.M. \& Babadagli, T. 2009. Laboratory and Field Scale Analysis of Steam Over Solvent Injection in Fractured Reservoirs (SOS FR) for Heavy Oil Recovery. Presented at the SPE Annual Technical Conference and Exhibition, New Orleans, 4-7 October. SPE-124047-MS, http://dx.doi.org/10.2118/124047-MS Al-Bahlani, A. M. \& Babadagli, T. 2011a. Field scale applicability and efficiency analysis of Steam-OverSolvent Injection in Fractured Reservoirs (SOS-FR) method for heavy oil recovery. J. Pet. Sci. Eng. v. 78 (2): p. 338-346, http://dx.doi.org/http://dx.doi.org/10.1016/j.petrol.2011.07.001

Al-Bahlani, A. M. \& Babadagli, T. 2011b. Steam-over-Solvent Injection in Fractured Reservoirs (SOS-FR) Technique as a New Approach for Heavy-Oil and Bitumen Recovery: An Overview of the Method: Energy Fuels, v. 25 (10): p. 4528-4539. http://dx.doi.org/10.1021/ef200809z

Alfahmi, M.M. 2018. Controls on fracture abundance in gently deformed carbonates, $\mathrm{PhD}$ thesis, University of Oxford, Oxford, $318 \mathrm{p}$ 
Aljariri Alhesan, J., Fei, Y., Marshall, M., Jackson, W., Qi, Y., Chaffee, A., \& Cassidy, P. 2018. Long time, low temperature pyrolysis of El-Lajjun oil shale. Journal of Analytical and Applied Pyrolysis, v. 130, p. 135-141, https://doi.org/10.1016/j.jaap.2018.01.017

Ali Hussein, M., Alqudah, M., Podlaha, O.G., van den Boorn, S., Kolonic, S., \& Mutterlose, J. 2014a. Ichnofabrics of Eocene oil shales from central Jordan and their use for paleoenvironmental reconstructions. GeoArabia, v. 19 (1), p. 143-158

Ali Hussein, M., Alqudah, M., Van den Boorn, S., Kolonic, S., Podlaha, O.G., \& Mutterlose, J. 2014b. Eocene oil shales from Jordan- their petrography, carbon and oxygen stable isotopes. GeoArabia, v. 19, (3), p. 139-162 Alnawafleh, H.M. 2007. Geological Factors Controlling the Variability of Maastrichtian Bituminous Rocks in Jordan, PhD Thesis, The University of Nottingham, Nottingham.

Alnawafleh, H. M. \& Fraige, F.Y. 2015. Analysis of Selected Oil Shale Samples from El-Lajjun, Central Jordan. Geomaterials, v. 5, p. 77-84, http://dx.doi.org/10.4236/gm.2015.53008

Alqudah, M., Ali Hussein, M., Van den Boorn, S. Podlaha, O., \& Mutterlose, J. 2015. Biostratigraphy and depositional setting of Maastrichtian - Eocene oil shales from Jordan. Marine and Petroleum Geology, v. 60, p. 87-104, https://doi.org/10.1016/j.marpetgeo.2014.07.025

Al-Zoubi, A., \& Ben-Avraham, Z. 2002. Structure of the earth's crust in Jordan from potential field data. Tectonophysics, v. 346, p. 45-59

Aske, N., Kallevik, H., Sjoblom, J. 2001. Determination of saturate, aromatic, resin, and asphaltenic (SARA) components in crude oils by means of infrared and near-infrared spectroscopy. Energy Fuels, v. 15, p. 13041312

Aydin, A. 2000. Fractures, faults, and hydrocarbon entrapment, migration and flow. Marine and Petroleum Geology, v. 17, no. 7, p. 797-814

Beaudoin, N. D., Huyghe, N., Bellahsen, O., Lacombe, L., Emmanuel, F., Mouthereau, \& Ouanhnon, L. 2015. Fluid systems and fracture development during syn-depositional fold growth: An example from the Pico del Aguila anticline, Sierras Exteriores, southern Pyrenees, Spain. Journal of Structural Geology, v. 70(C), p. 23-38, doi:10.1016/j.jsg.2014.11.003

Bons, P.D., Arnold, J., Elburg, M.A., Kalda, J., Soesoo, A., \& van Milligen, B. P. 2004. Melt extraction and accumulation from partially molten rocks. Lithos, v. 78, p. 25-42, doi:10.1016/j.lithos.2004.04.041 
Bons, P.D., Elburg, M.A. and Gomez-Rivas, E. 2012. A review of the formation of tectonic veins and their microstructures. Journal of Structural Geology, v. 43, p. 33-62

Burnham, A.K. 2017. Global Chemical Kinetics of Fossil Fuels. How to Model Maturation and Pyrolysis: Amsterdam, Springer, $330 \mathrm{p}$

Childs, C., Sylta, Ø., Moriya, S., Morewood, N., Manzocchi, T., Walsh, J. J., \& Hermanssen. D. 2009. Calibrating fault seal using a hydrocarbon migration model of the Oseberg Syd area, Viking Graben. Marine and Petroleum Geology, v. 26, Issue 6, p. 764-774. https://doi.org/10.1016/j.marpetgeo.2008.05.004 Comer, J.B. 2007. Reservoir Characteristics and Gas Production Potential of Woodford Shale in the Southern Mid Continent. Woodford Gas Shale Conference, Indiana Geological Survey, http://hdl.handle.net/2022/1826 Davletbaev, A., Kovaleva, L., \& Babadagli, T. 2011. Mathematical modeling and field application of heavy oil recovery by Radio-Frequency Electromagnetic stimulation. J. Pet. Sci. Eng. v. 78 (3-4): p. 646653, http://dx.doi.org/http://dx.doi.org/10.1016/j.petrol.2011.07.006

Diabat, A. 2009.Structural and stress analysis in Amman area, based on fault slip data. The 9th Jordanian Geological Conference and the 6th Geol. Symp. On Eastern Mediterranean Geology, Amman, 2- 5 April. Diabat, A., \& Masri, A. 2005. Orientation of the principal stresses along Zerqa-Ma'in Fault. Mu'tah Lil- Buhuth wad-Dirasat, v.20, p. 57-71

Dyni, John R. 2006. Geology and resources of some world oil-shale deposits. Scientific Investigations Report 2005-5294. U.S. Department of the Interior. U.S. Geological Survey. Retrieved 2007-07-09

Eichhubl, P., Aydin, A. \& Lore, J. 2001. Opening-mode fracture in siliceous mudstone at high homologous temperature —effect of surface forces. Geophysical Research Letter, v. 28, p. 1299-1302

Eichhubl, P. \& Aydin, A. 2003. Ductile opening-mode fracture by pore growth and coalescence during combustion alteration of siliceous mudstone. Journal of Structural Geology v. 25, p. 121-34

Figueroa Pilz, F., Dowey, P.J., Fauchille, A.L., Courtois, L., Bay, B., Ma, L., Taylor, K.G., Mecklenburgh, J., \& Lee, P. D. 2017. Synchrotron tomographic quantification of strain and fracture during simulated thermal maturation of an organic-rich shale, UK Kimmeridge Clay. J. Geophys. Res. Solid Earth, v. 122, p. 2553-2564, $\underline{\text { doi:10.1002/ 2016JB013874 }}$

Fink, R., Virgo, S., Arndt, M., Visser, W., Littke, R. \& Urai. J.L. 2016. Solid bitumen in calcite veins from the Natih Formation in the Oman Mountains: Multiple phases of petroleum migration in a changing stress field. 
International Journal of Coal Geology, v. 157, p. 39-51, ISSN 0166-5162,

https://doi.org/10.1016/j.coal.2015.07.012

Gradstein, F.M., Ogg, J.G., Schmitz, M., \& Ogg, G. 2012. Geologic Time Scale 2012. Elsevier B.V., Amsterdam

Gross, M.R., Fischer, M.P., Engelder, T. \& Greenfield, R. J. 1995. Factors controlling joint spacing in interbedded sedimentary rocks. Integrating numerical models with field observations from the Monterey

Formation, U.S.A., in M. S. Ameen, ed., Fractography. Fracture topography as a tool in fracture mechanics and stress analysis: Geological Society Special Publication, v. 92, p. 215-233

Hakimi, M.H., Abdullah, W.H., Alqudah, M., Makeen, Y.M., \& Mustapha, K.A. 2016. Organic geochemical and petrographic characteristics of the oil shales in the Lajjun area, Central Jordan: origin of organic matter input and preservation conditions. Fuel, v. 181, p. 34-45

Hakimi, M.H., Abdullah, W., Alqudah, M., Makeen, Y., Mustapha, K.A., \& Hatem. B. 2018. Pyrolysis analyses and bulk kinetic models of the Late Cretaceous oil shales in Jordan and their implications for early mature sulphur-rich oil generation potential. Marine and Petroleum Geology, v. 91, p. 764-775, https://doi.org/10.1016/j.marpetgeo.2018.01.036

Hamarneh, Y. 1998. Oil shale resources development in Jordan. Amman, Natural Resources Authority, Hashemite Kingdom of Jordan, p 98

Hilgers, C., \& Urai, J. L. 2002. Microstructural observations on natural syntectonic fibrous veins: implications for the growth process. Tectonophysics, v. 352, p. 257-274

Hooker, J. N., Huggett, J. M., Cartwright, J., \& Ali Hussein, M. 2017. Regional-scale development of openingmode calcite veins due to silica diagenesis. Geochem. Geophys. Geosyst., v. 18, p. 2580-2600, doi:10.1002/2017GC006888

Hooker, J. N., Abu-Mahfouz, I. S., Meng, Q., \& Cartwright. J. 2018. Fractures in mudrocks. Advances in constraining timing and understanding mechanisms: Journal of Structural Geology, in press, https://doi.org/10.1016/j.jsg.2018.04.020

Huang W.Y. \& Meinschein W.G. 1979. Sterols as ecological indicators. Geochim Cosmochim Acta, v. 43, p. $739-45$ 
Huggett, J., Hooker, J. N. \& Cartwright, J. 2017. Lithologic controls on diagenesis and diagenetic sequence in the Al Hasa phosphorite, Muwaqqar chalk marl, and Um Rijam chert formations, Jordan: Arabian J. Geosci., v. 10, p. 270, doi:10.1007/s12517-017-3038-5

Huang W.Y., \& Meinschein W.G. 1979. Sterols as ecological indicators. Geochim Cosmochim Acta 43:739745

Jaber, J. O., Probert, S. D., and Badr, O. 1997. Prospects for the exploitation of Jordanian oil shale. Oil Shale, v. 14(4), p. $565-578$

Jochum, J., Friedrich, G., Leythaeuser, D., Littke, R., \& Ropertz. B. 1995. Hydrocarbon-bearing fluid inclusions in calcite-filled horizontal fractures from mature Posidonia Shale (Hils Syncline, NW Germany). Ore Geol. Rev., v. 9, p. 363-370

Jones, G., Fisher, O.J. \& Knipe, R.J. 1998. Faulting, fault sealing and fluid flow in hydrocarbon reservoirs. London Geological Society, Special Publication, v. 147, 319 p

Lüning, S., \& Kuss. J. 2014. Petroleum geology of Jordan, in Petroleum Systems of the Tethyan Region, edited by L. Marlow, C. Kendall, \& L. Yose. AAPG Mem., v. 106, p. 217-239

Mandl, G., \& Harkness, R.M. 1987. Hydrocarbon migration by hydraulic fracturing. In M. E. Jones, \& R. M. F. Preston, Deformation of sediments and sedimentary rocks. Geological Society Special Publication, v. 29, pp. $39-53$

März, C., Wagner, T., Aqleh, S., Al-Alaween, M., van den Boorn, S., Podlaha, O.G., Kolonic, S., Poulton, S.W., Schnetger, B., \& Brumsack, H.J.,2016, Repeated enrichment of trace metals and organic carbon on an Eocene high-energy shelf caused by anoxia and reworking. Geology, v. 44 (12), pp.1011-1014, doi:

https://doi.org/10.1130/G38412.1

McDermott, C. I., Edlmann, K. \& Haszeldine, R.S., 2013, Predicting hydraulic tensile fracture spacing in stratabound systems. International Journal of Rock Mechanics and Mining Sciences, v. 63, p. 39-49, doi.org/10.1016/j.ijrmms.2013.06.004

Mello, M.R., Telnaes, N., Gaglianone, P.C., Chicarelli, M. I., Brassell, S.C., \& Maxwell, J.R. 1988. Organic geochemical characterisation of depositional palaeoenvironments of source rocks and oils in Brazilian marginal basins. Organic Geochemistry, v. 13, p. 31-45 
Michels, R., Landais, P., Philp, R.P., \& Torkelson, B.E. 1994. Effects of pressure on organic matter maturation

725

726

727

728

729

730

731

732

733

734

735

during confined pyrolysis of Woodford kerogen. Energy Fuel, v. 8 (3), p. 741-754

Mueller, E., \& Philp, E. 1998. Extraction of high molecular weight hydrocarbons from source rocks: an example from the Green River Formation, Uinta Basin, Utah. Organic Geochemistry, v. 28, Issues 9-10, p. 625631, https://doi.org/10.1016/S0146-6380(98)00031-X

Meng, Q., Hooker, J. N. \& Cartwright. J. 2017. Early overpressuring in organic-rich shales during burial.

Evidence from fibrous calcite veins in the Lower Jurassic Shales-with-Beef Member in the Wessex Basin, UK:

J. Geol. Soc., doi:10.1144/jgs2016-146

Nelson, R.A. 1985. Geological Analysis of Naturally Fractured Reservoirs: Houston TX, Gulf Publishing, 332 p.

Olson, J.E., Laubach, S.E. \& Lander, R.H. 2009. Natural fracture characterization in tight gas sandstones: integrating mechanics and diagenesis. AAPG Bull. v. 93, p. 1535-1549, doi: 10.1306/08110909100

Parnell, J., Robinson, N. \& Brassell, S. 1991. Discrimination of bitumen sources in Precambrian and Lower Palaeozoic rocks, southern U.K., by gas chromatography-mass spectrometry. Chemical Geology, v. 90, p. 1-14 Parnell, J., Geng, A., Fu, J., \& Sheng, G. 1994. Geology and geochemistry of bitumen vein deposits at Ghost City, Junggar Basin, northwest China. Geol. Mag. v. 131, p. 181-190

Parnell, J., \& Carey, P. F. 1995. Emplacement of bitumen (asphaltite) veins in the Neuquen Basin, Argentina. AAPG Bulletin, v. 79 (12), p. 1798-1816

Parnell, J., Carey, P. \& Monson, B. 1998. Timing and temperature of decollement on hydrocarbon source rock beds in cyclic lacustrine successions. Palaeogeography, Palaeoclimatology, Palaeoecology, v. 140, p. 121-134

Parnell, J., Baron, M., Mann, P., \& Carey, P. 2003. Oil migration and bitumen formation in a hydrothermal system, Cuba. Journal of Geochemical Exploration, v. 78-79, p. 409-415, https://doi.org/10.1016/S0375$\underline{6742(03) 00018-9}$

Parnell, J., Baba, M., Bowden, S., \& Muirhead, D. 2017a. Subsurface biodegradation of crude oil in a fractured basement reservoir, Shropshire, UK. Journal of the Geological Society, v. 174, p. 655-

666, https://doi.org/10.1144/jgs2016-129 
Parnell, J., Baba, M., \& Bowden, S. 2017b. Emplacement and biodegradation of oil in fractured basement: The 'coal' deposit in Moinian gneiss at Castle Leod, Ross-shire. Earth and Environmental Science Transactions of the Royal Society of Edinburgh, 107(1), 23-32. doi:10.1017/S1755691017000056

Passchier, S. 2000. Soft-sediment deformation features in core from CRP-2/2A, Victoria Land Basin, Antarctica, Terra Antartica, Bremerhaven, PANGAEA, v. 7 (3), p. 401-412

Pathak, V., Babadagli, T., \& Edmunds, N. 2013. Experimental Investigation of Bitumen Recovery from Fractured Carbonates Using Hot Solvents. Society of Petroleum Engineers, v. 52, doi:10.2118/159439-PA

Pepper, A. 2017. Definition, Modes of Occurrence and Pitfalls in Understanding the Term 'Bitumen' in Conventional and Unconventional Petroleum Systems. paper presented to AAPG Annual Convention and Exhibition, Houston, Texas.

http://www.searchanddiscovery.com/abstracts/html/2017/90291ace/abstracts/2613048.html.

Peters, K.E., \& Moldowan, J. 1993. The biomarker Guide. Interpreting molecular fossils in petroleum and ancient sediments, Prentice hall, Englewood cliffs, NJ, 363 p

Peters, K.E., Moldowan, J.M., McCaffrey, M.A., \& Fago, F.J. 1996. Selective biodegradation of extended hopanes to 25-norhopanes in petroleum reservoirs. Insights from molecular mechanics; Organic

Geochemistry, v. 24, p. $765-783$

Peters, K.E., Walters, C. \& Moldowan, J. 2005. The Biomarker Guide. Biomarkers and isotopes in petroleum systems and Earth history: New York, Cambridge university press, v. 2, 2nd edition.

Powell, J.1989. Stratigraphy and Sedimentation of the Phanerozoic Rocks in Central and South Jordan; Part B, Kurnub, Ajlun and Belqa Groups. Geol. Mapping Div. Bull. 11A, Natural Resources Authority, Amman Powell, J., \& Moh'd, B. 2011. Evolution of Cretaceous to Eocene alluvial and carbonate platform sequences in central and south Jordan. GeoArabia, v. 16 (4), p. 29-82

Prajapati, N., Selzer, M., Nestler, B., Busch, B., and Hilgers. C., 2018, Modeling fracture cementation processes in calcite limestone: a phase-field study: Geotherm Energy. v. 6: 7. https://doi.org/10.1186/s40517-018-0093-4 
Priest, S. D., \& Hudson, J. A., 1981, Estimation of discontinuity spacing and trace length using scanline surveys: International Journal of Rock Mechanics and Mining Sciences and Geomechanics Abstracts, v. 18, p. 183-197.

Priest, S. D., 1993, Discontinuity analysis for rock engineering: London, Chapman \& Hall, 473 p. Ryder, R. T., Hackley, P. C. Trippi, M. H., \& Alimi. H., 2013, Evaluation of thermal maturity in the low maturity Devonian shales of the northern Appalachian Basin: AAPG Search and Discovery Article 10477. Parts 1 (67 p.) and 2 (177 p.) http://www.searchanddiscovery.com/documents/2013/10477ryder/ndx_ryder.pdf

Secor, D.T. 1965. Role of fluid pressure in jointing: American Journal of Science, v. 263, p. 633-646.

Segev, A., Lyakhovsky, V., \& Weinberger, R. 2014. Continental transform-rift interaction adjacent to a continental margin: The Levant case study: Earth-Science Reviews, v. 139, p. 83-103, https://doi.org/10.1016/j.earscirev.2014.08.015

Seifert W. K., \& Moldowan J. M., 1981, Paleoconstruction by biological markers: Geochim Cosmochim Acta; v. 45, no. 6, p. 783-794, doi: 10.1016/0016-7037(81)90108-3

Selby, D. \& Creaser, R. A. 2005. Direct radiometric dating of hydrocarbon deposits using rhenium-osmium isotopes: Science, v. 308, p. 1293 - 1295, doi: 10.1126/science.1111081

Sinninghe-Damste, J., Kenig, F., Koopmans, M., Koster, J., Schouten, S., Hayes, J., \& DeLeeuw, J., 1995, Evidence for gammacerane as an indicator of water column stratification: Geochimica et Cosmochimica Acta, v. 59, p.1895-1900.

Sokol E. V., Kozmenko O. A., Khoury H. N., Kokh S. N., Novikova S. A., Nefedov A. A., Sokol I. A., \& Zaikin P. 2017. Calcareous sediments of the Muwaqqar chalk marl formation, Jordan: mineralogical and geochemical evidences for $\mathrm{Zn}$ and Cd enrichment: Gondwana Res, v. 46, p. 204226, https://doi.org/10.1016/j.gr.2017.03.008

Stern, R. J. \& Johnson, P. 2010. Continental lithosphere of the Arabian Plate: A geologic, petrologic, and geophysical synthesis: Earth Science Reviews, v. 101, p. 29-67

Teufel, L. W., \& Clark, J. A. 1984. Hydraulic fracture propagation in layered rocks: experimental studies of fracture containment: Soc Petrol Eng J, v. 24, p. 19-32 
Tissot B. P., \& Welte D. H. 1984. Diagenesis, Catagenesis and Metagenesis of Organic Matter: Petroleum Formation and Occurrence., Berlin, Heidelberg, Springer, p. 69-73, https://doi.org/10.1007/978-3-642-964466_6

Verbeek, E. R., \& Grout, M. A., 1992, Hydrocarbon and mineral resources of the Uinta Basin, Utah and Colorado ed T D Fouch, V F Nuccio et al (Salt Lake: Utah Geological Association Guidebook 20) Structural evolution of gilsonite dikes, eastern Uinta Basin, Utah, p. 237-255

Volkman J. K.. 1986. A review of sterol biomarkers for marine and terrigenous organic matter: Org Geochem, v. 9 , p. $83-9$

Wang, G., Wang, T. G., Han, K., Wang, L. \& Chi, S. 2015. Recognition of a novel Precambrian petroleum system based on isotopic and biomarker evidence in the Yangtze platform, South China: Marine and Petroleum Geology, v. 68, p. 414-426. doi.org/10.1016/j.marpetgeo.2015.09.003

Wang H., Yao Y., Liu D., Pan , Z., Yang, Y., \& Cai Y. 2016. Fault-sealing capability and its impact on coalbed methane distribution in the Zhengzhuang field, southern Qinshui Basin, North China: Journal of Natural Gas Science and Engineering, v. 28, p. 613-625. doi: 10.1016/j.jngse. 2015.12.036.

Wilhelms, A., Larter, S. R., Head, I., Farrimond, P., di-Primio, R. \& Zwach, C. 2001. Biodegradation of oil in uplifted basins prevented by deep-burial sterilization: Nature, v. 411, p. 1034-1037

Yassini, I. 1979. Maastrichtian-Lower Eocene biostratigraphy and the planktonic foraminiferal biozonation in Jordan: Rev. Esp. Micropaleontol. 11, 5e57

Zeeb, C., Gomez-Rivas, E., Bons, P. D., \& Blum, P. 2013. Evaluation of sampling methods for fracture network characterization using outcrops: AAPG Bull., v. 97, p. 1545-1566, doi:10.1306/02131312042

Zhang, J., Z. Jiang, X. Jiang, S. Wang, C. Liang, \& M. Wu. 2016. Oil generation induces sparry calcite formation in lacustrine mudrock, Eocene of east China: Mar. Pet. Geol., v. 71, p. 344-359,

doi.org/10.1016/j.marpetgeo.2016.01.007

\section{Figure captions}

Fig. 1. (a) Structural map of Jordan, showing the location of the studied fifteen cores and the outcrop in Central and South Jordan, and the main structural elements in the region (Modified after Diabat \& Masri 2005). Numbers from 1 to 15 represent the studied cores (C1-C15). (b) The stratigraphy of the Belqa Group in outcrop and subsurface. Blue shaded part represents the studied succession (modified after Ali 
Hussein et al. 2014b). (c) and (d) Schematic E-W and N-S structural cross sections across the area of Jordan (modified after Lüning \& Kuss 2014 and Natural Resources Authority of Jordan (NRA 2001).

Fig. 2. (a) A columnar section showing the lithology of the studied cored intervals. (b) A representative trend (from core 10) of vertical frequency and distribution of all fractures and bitumen-bearing fractures against the three lithological units. Zoomed in area demonstrates the relationship between fracture intensity and the TOC and TS of the lower unit. Red-shaded rectangles show low fracture intensity correlate with low TOC and TS values. Green-shaded rectangles show high fracture intensity correlates with high TOC and TS values. (c). Schematic drawing showing the age difference of the JOS in different cores from central west, central east and south Jordan (modified after Alqudah et al. 2015). C5 in this study is equivalent to OS22, C8 to OS28 and C13 to OS1 in the Alqudah et al. (2015) study (see supplementary Table for more information). Absolute ages after Gradstein et al. (2012).

Fig. 3. (a) Schematic burial history curve of the JOS in the Harrana area (CW) and (b) in the Azraq area (CE).

Fig. 4. Plots showing (a) the frequency of all opening-mode fractures in the core and (b) The frequency of veins (planar and folded veins).

Fig. 5. Slabbed core images of different bitumen-bearing fractures. B, Bitumen; BCV, Bitumen-Bearing Calcite Vein; CV, Calcite Vein; BV, Bitumen Vein; SV, Silica Vein; FCV, Folded Calcite Vein, BMF, Bitumen Microfracture; S. Mudstone, Silicified mudstone. (a) BCV propagates across chert nodule, silicified mudstone, and organic-rich mudstone. Note the deflection of vein when the bed lithology changes (blue arrows). (b) BVs confined to chert beds and carbonate concretion. Note the low-organic matter zone in the mudstone bed underlying the chert bed (yellow dotted), indicating that bitumen has escaped towards the chert bed (white-dashed arrow). (c) Bitumen-bearing calcite veins confined to chert beds/lenses; demonstrating the role of mechanical stratigraphy in fracturing. (d) Bitumen vein propagates through three different types of lithologies (mudstone, chert and carbonate concretion). Note the increase in aperture size of the vein in the chert and carbonate concretions. (e) BV open towards the 
chert concretion. Note the low-organic matter zone in the mudstone bed overlying the chert concretion (yellow dotted); indicates bitumen migration towards the centre of the chert concretion (white-dashed arrow). (f) Two fracture networks of horizontal and vertical SVs and BVs. BVs crosscut SVs (Blue arrow). (g) Mosaic brecciation in the organic-rich mudstone.

Fig. 6. Core and field photographs of different bitumen-bearing veins. BCV, Bitumen-bearing Calcite Vein; BV, Bitumen Vein; SV, Silica Vein; FCV, Folded Calcite Vein; S. Mudstone, Silicified mudstone. (a) SVs and BVs in organic-rich mudstone. (b) Schematic drawing of (a). Note the crosscutting relationship between silica veins and bitumen veins (blue arrows). (c) Field photograph of vertical BVs confined to the oil shale bed at the El-Lajjun quarry. (d) Bitumen in veins and pores (vugs) in silicified limestone beds in the lower unit of core C8. Yellow diamonds show the maximum aperture size of the bitumen vein. (e) Bitumen vein propagates in mudstone and chert beds. Note the branching of the bitumen vein in the mudstone bed (yellow arrow). (f) Horizontal BCV crosscut folded calcite veins in organic-rich mudstone. (g) Schematic drawing of (f). Note the crosscutting relationships between the horizontal bitumen-bearing vein and folded veins (blue arrows).

Fig. 7. Micrographs of different bitumen-bearing fractures. BCV, Bitumen-bearing Calcite Vein; B, Bitumen; BP, Bitumen-bearing pore, BMV, Bitumen Micro-Vein; BV, Bitumen Vein. (a) BCV shows crack-seal texture. Note the bitumen inclusions within calcite cement. (b) Schematic drawing of (a). (c) BSE image shows sub-horizontal microfractures, pores and microfossils filled with bitumen. Note Microfracturing of grains. (d) EDS map of the bitumen microveins shown in (c), showing the Carbon content in the bitumen microfractures and matrix in the lower unit of core. (e) Core photograph showing BVs in carbonate concretions hosted by organic-rich mudstone. (f) Micrograph of the inset in (e) showing the direction of bitumen migration inside both BV (white-dashed arrow) and BMV from the organic-rich mudstone bed towards the carbonate concretion. (g) Mosaic brecciation of mudstone by bitumen overpressure. 
877 Fig. 8. Plot of Hydrogen index (HI) versus Tmax, showing maturity and kerogen quality of the Late

878 Cretaceous-Eocene oil shale samples.

879 Fig. 9. Examples of representative m/z 191 and m/z 217 fragmentograms showing the distribution of 880 terpanes and steranes, respectively, in studied matrix and fracture bitumen samples. Note the similarity 881 between the fracture (FB) and matrix bitumen (MB).

882 Fig. 10. Ternary diagram showing the distribution of C27, C28 and C29 $\alpha \alpha \alpha-\mathrm{R}$ steranes in the fracture 883 and matrix bitumen samples. Depositional environments after Huang \& Meinschein 1979.

884 Fig. 11. Plots of the hopane and sterane biomarkers ratios. a. 22S/(22S+22R) C31 Hopanes against 885 20S/(20S+20R) C28 Steranes. b: Gammacerane:C30 against C27 $\alpha \alpha \alpha R$.

886 Fig. 12. Bitumen mobilization due to mechanical compaction (a-d). (a) Organic particle at shallow 887 burial. (b) Mechanical compaction and water removal. (c) It becomes mechanically weak-loading and 888 extrudes bituminized OM. Occurs preferentially in OM with early generation kinetics and high HI. (d) 889 Saturation of the matrix followed by short-distance migration, creating fractures (modified after Pepper 890 2017).

891 Fig. 13. Paragenetic sequence of the fracture cements (modified after Hooker et al. 2017). 


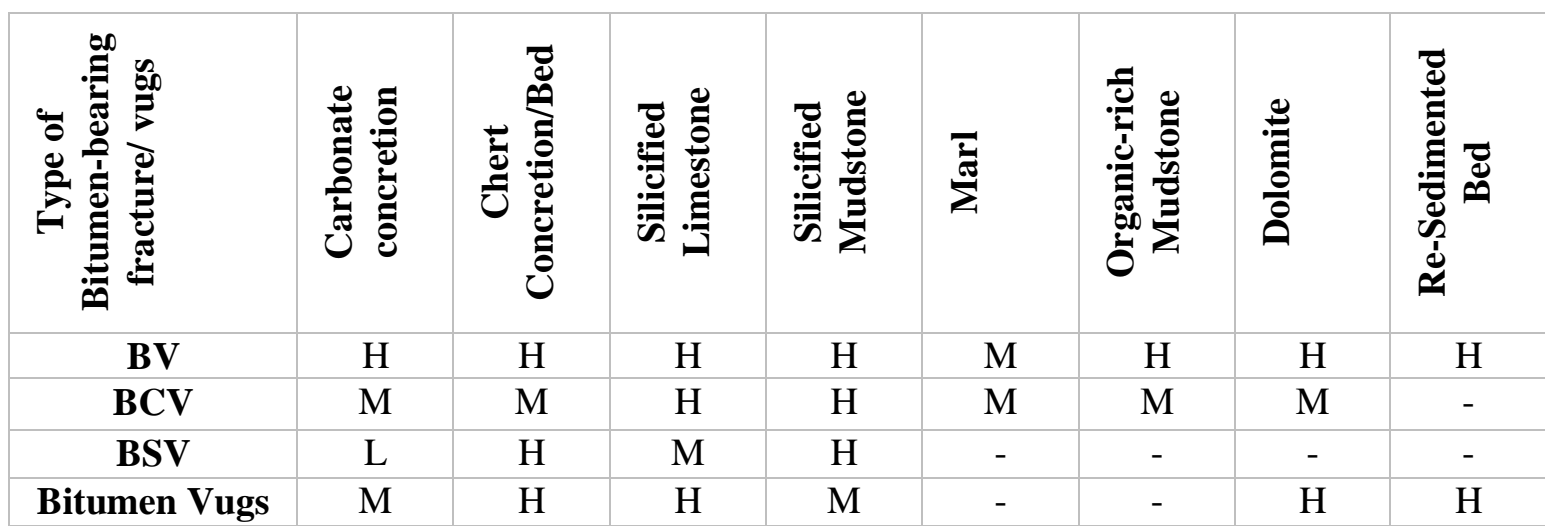

Table 1. Relative distribution of bitumen-bearing fractures and vugs (High: H,

Moderate: $M$, Low: L)

\begin{tabular}{|c|c|c|c|c|c|c|c|c|c|}
\hline Sample & $\begin{array}{c}\text { Sample } \\
\text { Type }\end{array}$ & $\begin{array}{c}\text { TOC } \\
(w t \%)\end{array}$ & $\begin{array}{c}\text { TS } \\
(\mathbf{w t} \%)\end{array}$ & $\begin{array}{c}\mathrm{S1} \\
\text { (mg/g rock) }\end{array}$ & $\begin{array}{c}\mathrm{S2} \\
(\mathrm{mg} / \mathrm{g} \text { rock) }\end{array}$ & $\begin{array}{l}\mathbf{T}_{\max } \\
\left({ }^{\circ} \mathbf{C}\right)\end{array}$ & $\begin{array}{c}\text { HI } \\
(\mathbf{m g ~ H C} / \mathbf{g} \\
\text { TOC) }\end{array}$ & $\begin{array}{c}\mathrm{OI} \\
(\mathrm{mg} \mathrm{CO} / \mathrm{g} \\
\mathrm{TOC})\end{array}$ & PI \\
\hline 1 & Core & 19.5 & 2.8 & 2.7 & 148.2 & 402.0 & 762.0 & 17.4 & 0.02 \\
\hline 2 & Core & 15.7 & 4.8 & 1.7 & 105.3 & 413.0 & 672.8 & 19.3 & 0.02 \\
\hline 3 & Core & 16.9 & 3.8 & 2.0 & 115.0 & 420.0 & 680.5 & 15.3 & 0.02 \\
\hline 4 & Core & 14.9 & 5.2 & 1.8 & 131.2 & 415.0 & 880.2 & 8.5 & 0.06 \\
\hline 5 & Core & 15.9 & 4.5 & 2.5 & 112.4 & 416.0 & 705.7 & 11.4 & 0.02 \\
\hline 6 & Core & 30.0 & 8.3 & 6.7 & 175.0 & 404.0 & 583.3 & 27.0 & 0.04 \\
\hline 7 & Core & 14.1 & 2.3 & 0.9 & 104.5 & 416.0 & 743.5 & 9.3 & 0.01 \\
\hline 8 & Core & 17.9 & 4.3 & 5.5 & 115.9 & 424.0 & 647.5 & 14.2 & 0.05 \\
\hline 9 & Core & 20.2 & 4.3 & 1.9 & 130.0 & 395.0 & 642.9 & 12.9 & 0.04 \\
\hline 10 & Core & 13.9 & 6.5 & 2.0 & 97.8 & 404.0 & 703.6 & 15.2 & 0.02 \\
\hline 11 & Core & 14.9 & 3.7 & 1.4 & 100.1 & 405.0 & 670.7 & 12.0 & 0.01 \\
\hline 12 & Outcrop & 21.3 & 3.9 & 4.6 & 132.3 & 416.0 & 621.1 & 13.7 & 0.03 \\
\hline 13 & Core & 6.1 & 1.5 & 0.5 & 45.0 & 403.0 & 734.1 & 18.0 & 0.01 \\
\hline 14 & Core & 12.4 & 2.8 & 1.8 & 90.3 & 409.0 & 726.6 & 13.0 & 0.02 \\
\hline 15 & Core & 17.4 & 3.8 & 3.8 & 119.4 & 407.0 & 688.1 & 12.7 & 0.03 \\
\hline 16 & Core & 11.7 & 4.7 & 2.5 & 90.4 & 389.2 & 771.9 & 14.3 & 0.06 \\
\hline
\end{tabular}

Table 2. Bulk organic geochemical properties of the JOS matrix in the lower unit of the studied succession 


\begin{tabular}{|c|c|c|c|c|c|c|c|c|c|c|c|}
\hline \multirow[b]{2}{*}{ Sample } & \multicolumn{3}{|c|}{ Hopanes Data } & \multicolumn{8}{|c|}{ Steranes Data } \\
\hline & Gammacerane:C30 & C29:C30 & $\begin{array}{r}\text { 22S/(22S+22R }) \\
\text { C31 Hopanes }\end{array}$ & \%C27 $\alpha \alpha \alpha R$ & \%C28 $\alpha \alpha \alpha R$ & \%C29 $\alpha \alpha \alpha R$ & C27:C28 & C27:C29 & C28:C29 & $\begin{array}{c}\alpha \beta \beta /(\alpha \beta \beta+\alpha \alpha \alpha) \\
\text { C28 Steranes }\end{array}$ & $\begin{array}{c}20 S /(20 S+20 R) \\
\text { C28 Steranes }\end{array}$ \\
\hline FB1 & 0.48 & 0.52 & 0.21 & 52 & 25 & 23 & 2.10 & 2.32 & 1.11 & 0.59 & 0.30 \\
\hline FB2 & 0.37 & 0.39 & 0.25 & 55 & 21 & 24 & 2.61 & 2.24 & 0.86 & 0.59 & 0.25 \\
\hline FB3 & 0.79 & 0.60 & 0.53 & 48 & 26 & 26 & 1.85 & 1.85 & 1.00 & 0.51 & 0.52 \\
\hline FB4 & 0.79 & 0.53 & 0.54 & 47 & 27 & 25 & 1.72 & 1.85 & 1.07 & 0.49 & 0.51 \\
\hline FB5 & 0.46 & 0.27 & 0.53 & 58 & 20 & 22 & 2.88 & 2.58 & 0.89 & 0.49 & 0.47 \\
\hline FB6 & 0.47 & 0.38 & 0.56 & 52 & 23 & 25 & 2.23 & 2.04 & 0.92 & 0.55 & 0.42 \\
\hline FB7 & 0.45 & 0.38 & 0.56 & 48 & 24 & 27 & 2.00 & 1.77 & 0.88 & 0.54 & 0.39 \\
\hline FB8 & 0.87 & 0.35 & 0.55 & 54 & 20 & 26 & 2.67 & 2.09 & 0.78 & 0.63 & 0.40 \\
\hline FB9 & 0.90 & 0.33 & 0.60 & 57 & 20 & 23 & 2.82 & 2.53 & 0.89 & 0.63 & 0.43 \\
\hline FB10 & 0.93 & 0.28 & 0.55 & 57 & 18 & 25 & 3.21 & 2.25 & 0.70 & 0.65 & 0.42 \\
\hline FB11 & 0.89 & 0.36 & 0.60 & 58 & 21 & 22 & 2.81 & 2.65 & 0.94 & 0.66 & 0.43 \\
\hline FB12 & 0.44 & 0.44 & 0.28 & 53 & 21 & 26 & 2.58 & 2.04 & 0.79 & 0.50 & 0.24 \\
\hline MB1 & 0.57 & 0.43 & 0.19 & 53 & 23 & 24 & 2.33 & 2.23 & 0.95 & 0.59 & 0.28 \\
\hline MB2 & 0.38 & 0.27 & 0.22 & 53 & 20 & 27 & 2.67 & 2.00 & 0.75 & 0.53 & 0.25 \\
\hline MB3 & 0.77 & 0.54 & 0.55 & 49 & 23 & 27 & 2.11 & 1.82 & 0.86 & 0.41 & 0.51 \\
\hline MB4 & 0.76 & 0.49 & 0.56 & 47 & 24 & 29 & 1.96 & 1.63 & 0.83 & 0.51 & 0.52 \\
\hline MB5 & 0.40 & 0.38 & 0.56 & 55 & 22 & 24 & 2.53 & 2.29 & 0.90 & 0.59 & 0.44 \\
\hline MB6 & 0.38 & 0.52 & 0.55 & 56 & 20 & 24 & 2.72 & 2.33 & 0.86 & 0.57 & 0.44 \\
\hline MB7 & 0.34 & 0.53 & 0.57 & 56 & 21 & 23 & 2.72 & 2.45 & 0.90 & 0.57 & 0.38 \\
\hline MB8 & 0.84 & 0.28 & 0.57 & 55 & 21 & 24 & 2.67 & 2.29 & 0.86 & 0.64 & 0.42 \\
\hline MB9 & 0.88 & 0.29 & 0.58 & 55 & 20 & 25 & 2.67 & 2.18 & 0.82 & 0.62 & 0.45 \\
\hline MB10 & 0.91 & 0.33 & 0.56 & 54 & 20 & 26 & 2.67 & 2.09 & 0.78 & 0.63 & 0.42 \\
\hline MB11 & 0.83 & 0.36 & 0.56 & 52 & 23 & 24 & 2.23 & 2.13 & 0.96 & 0.60 & 0.45 \\
\hline MB12 & 0.45 & 0.41 & 0.27 & 51 & 16 & 30 & 2.58 & 1.69 & 0.66 & 0.52 & 0.21 \\
\hline
\end{tabular}

Table 3. Biomarker data extracted from $\mathrm{m} / \mathrm{z}, 191$ and $\mathrm{m} / \mathrm{z}, 217$ fragmentograms of the analysed matrix and fracture samples 


\section{Figure 1}

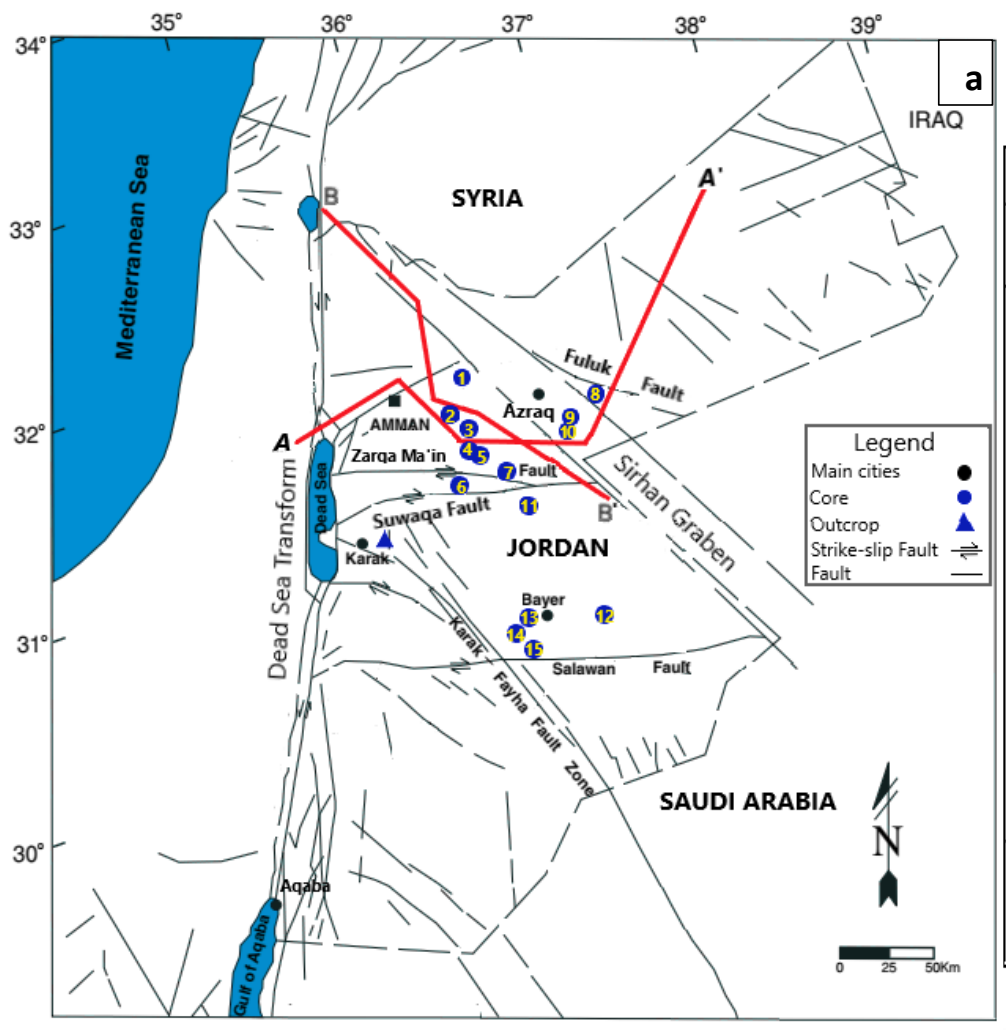

\begin{tabular}{|c|c|c|c|c|c|c|}
\hline \multicolumn{2}{|c|}{ Chronostratigraphy } & & Subsurface Formation \\
(Andrews, 1992)
\end{tabular}

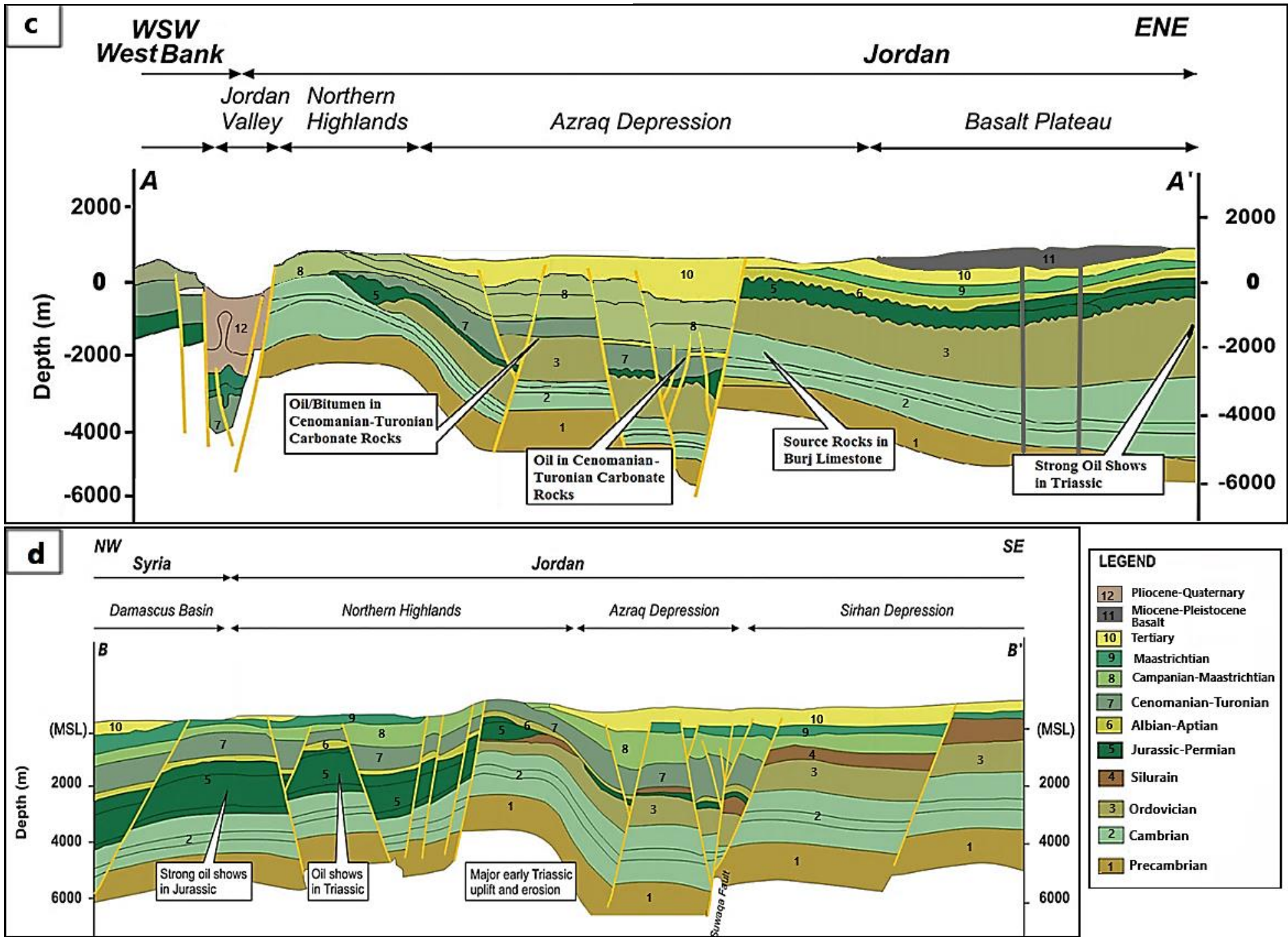

ENE

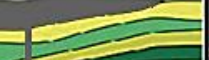

0

$-2000$

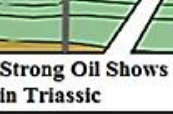

shows

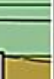

$-4000$

$-6000$ 
Figure 2

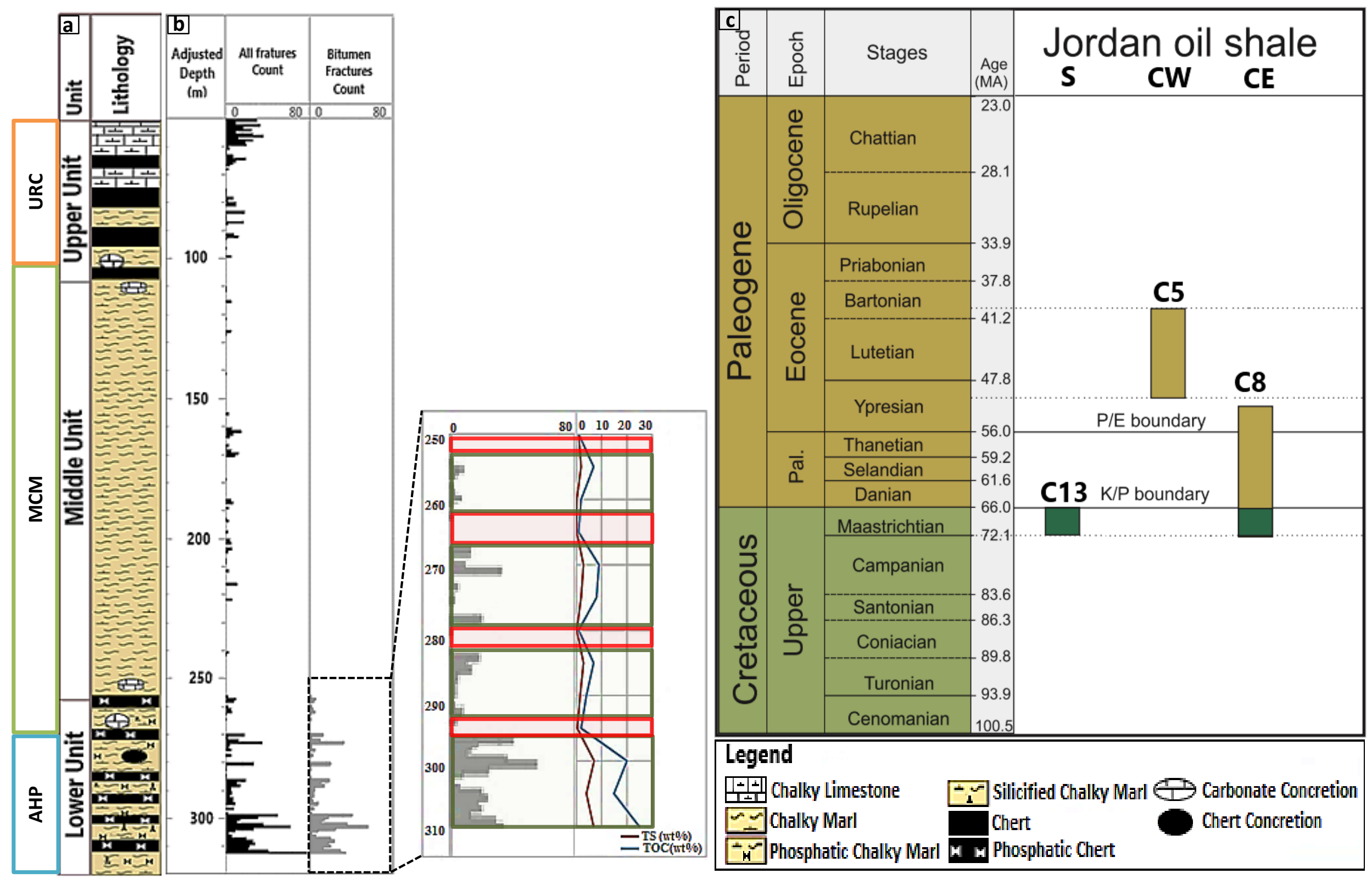


Figure 3
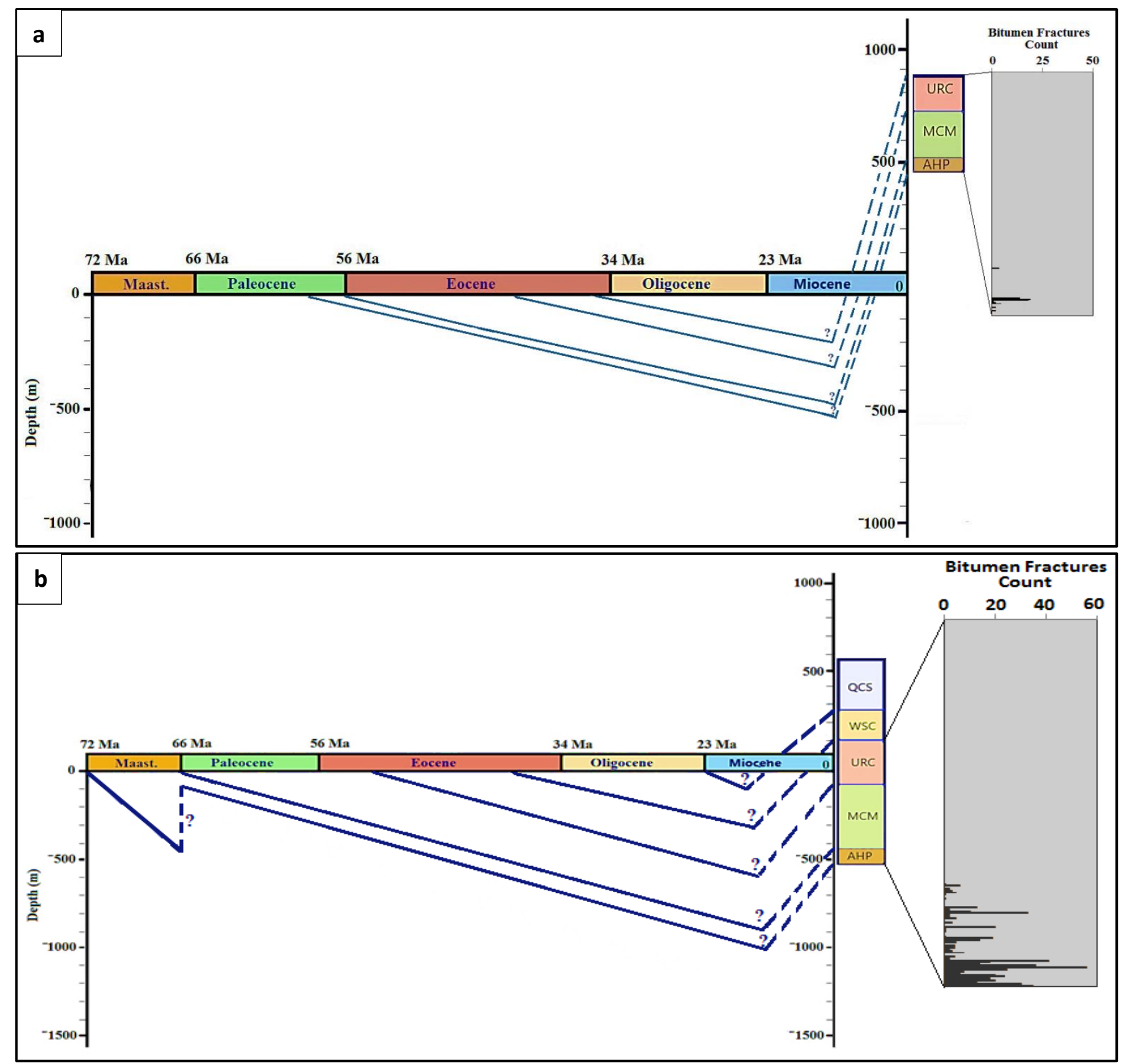

Figure 4
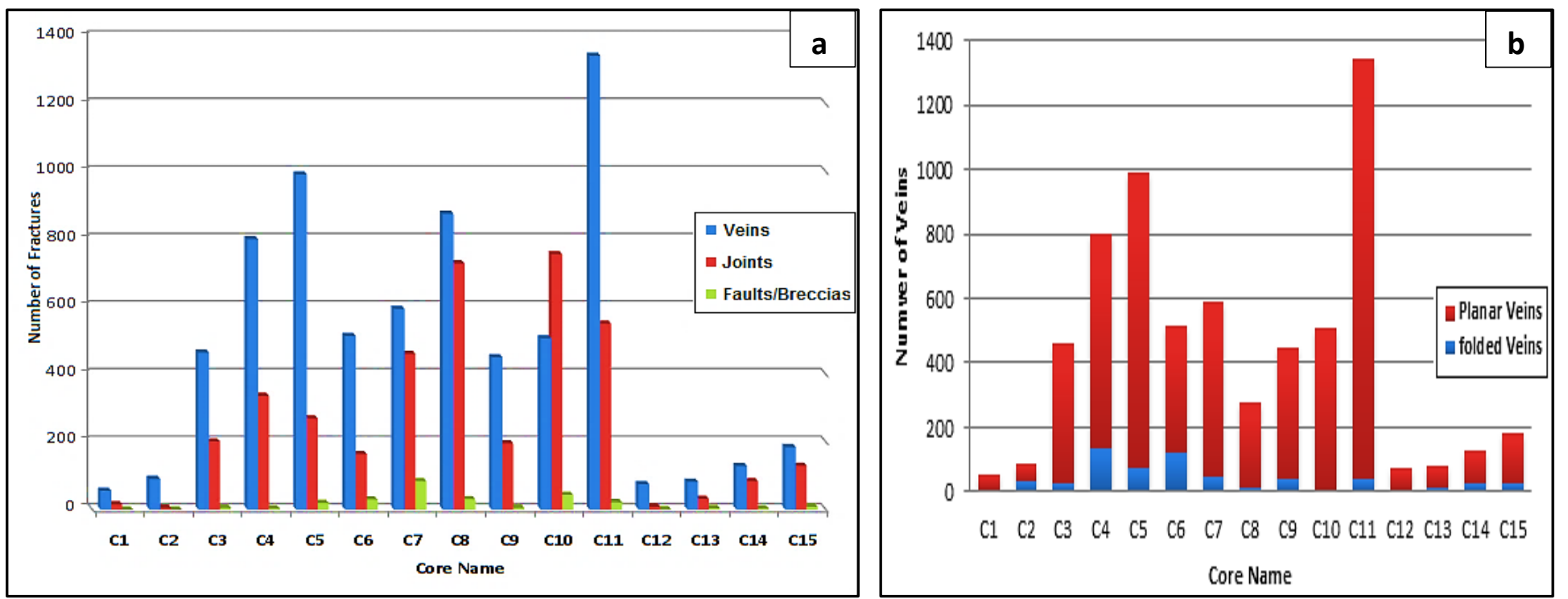
Figure 5
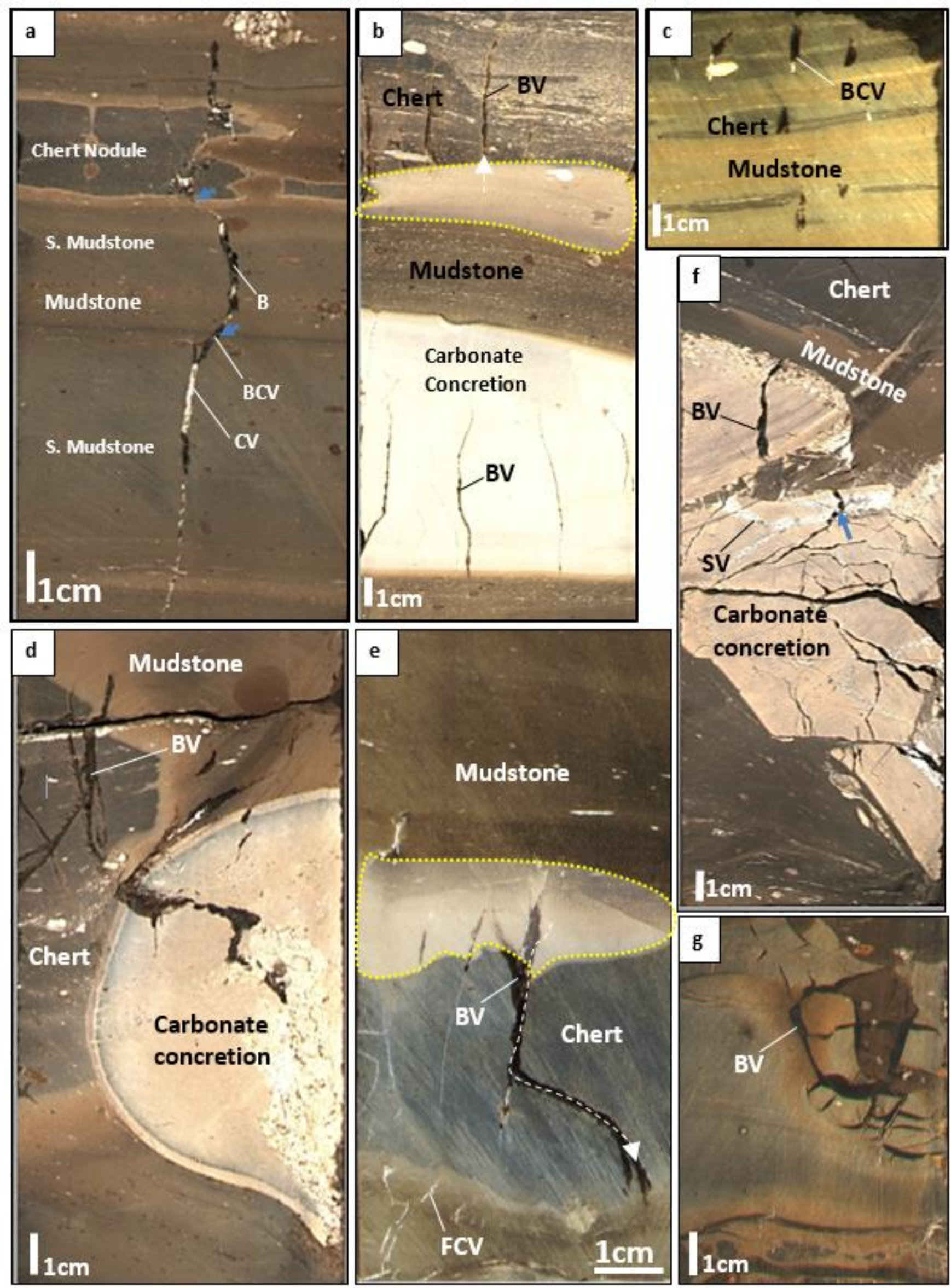
Figure 6

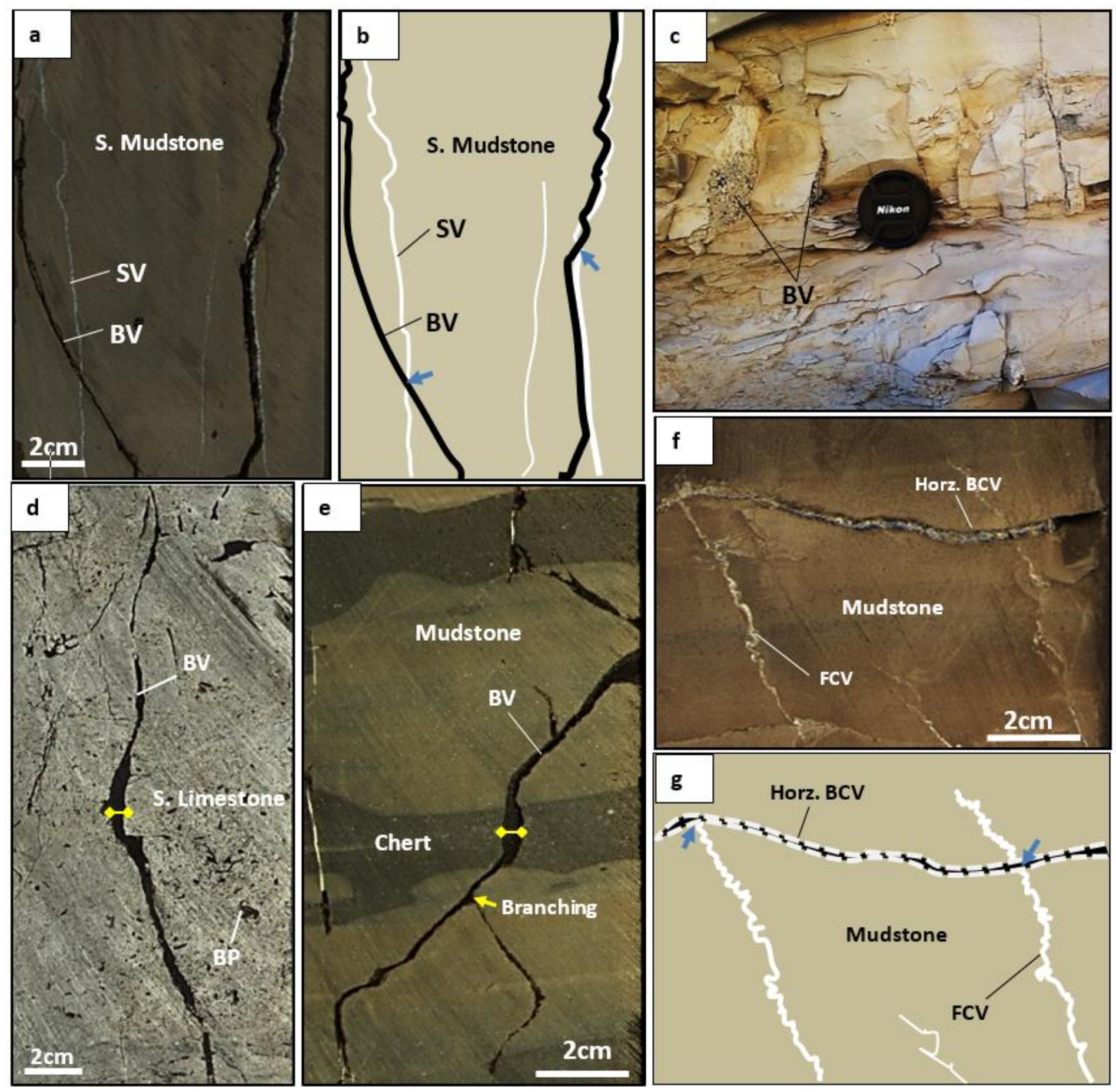


Figure 7
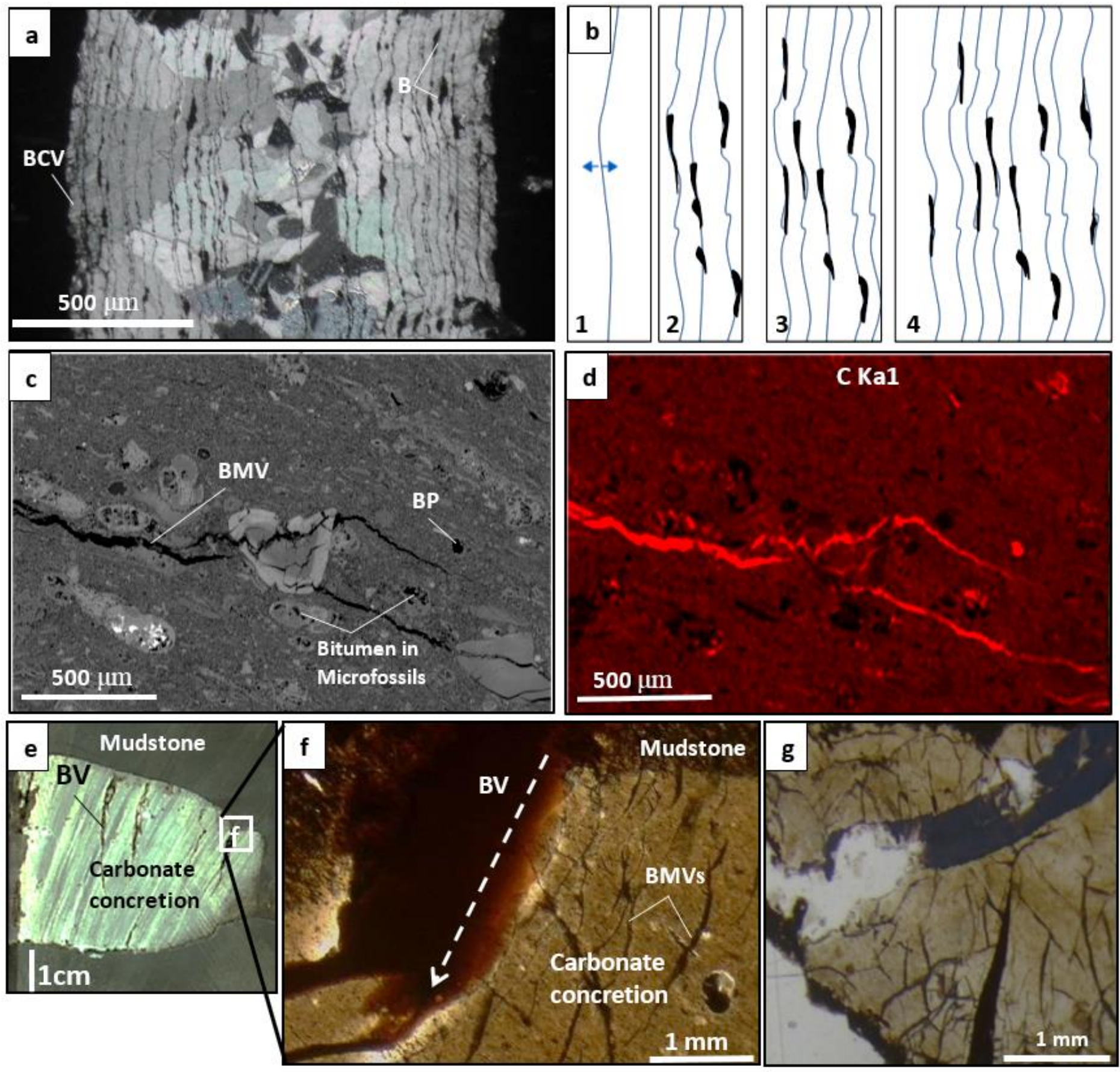
Figure 8

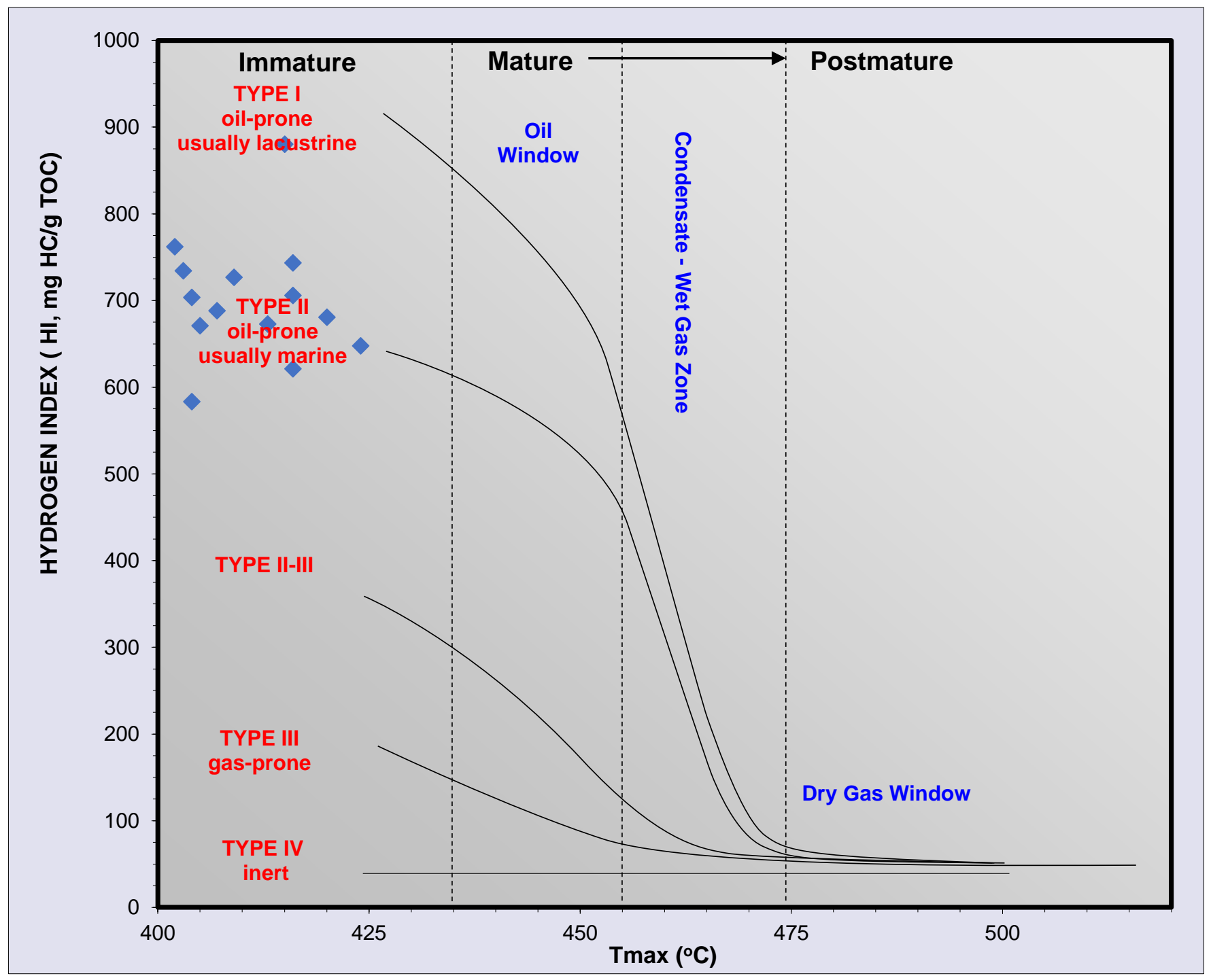


Figure 9

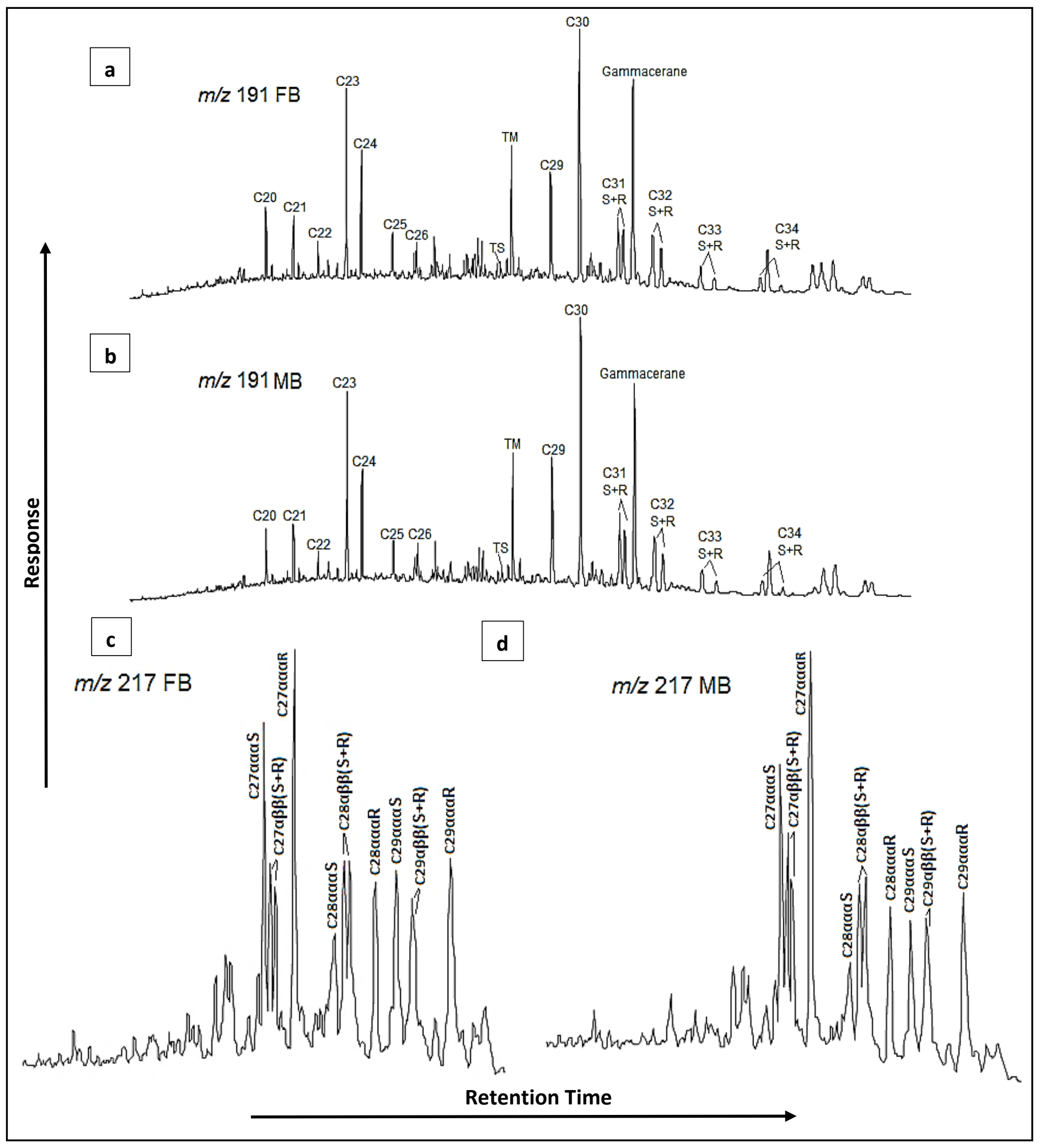


Figure 10

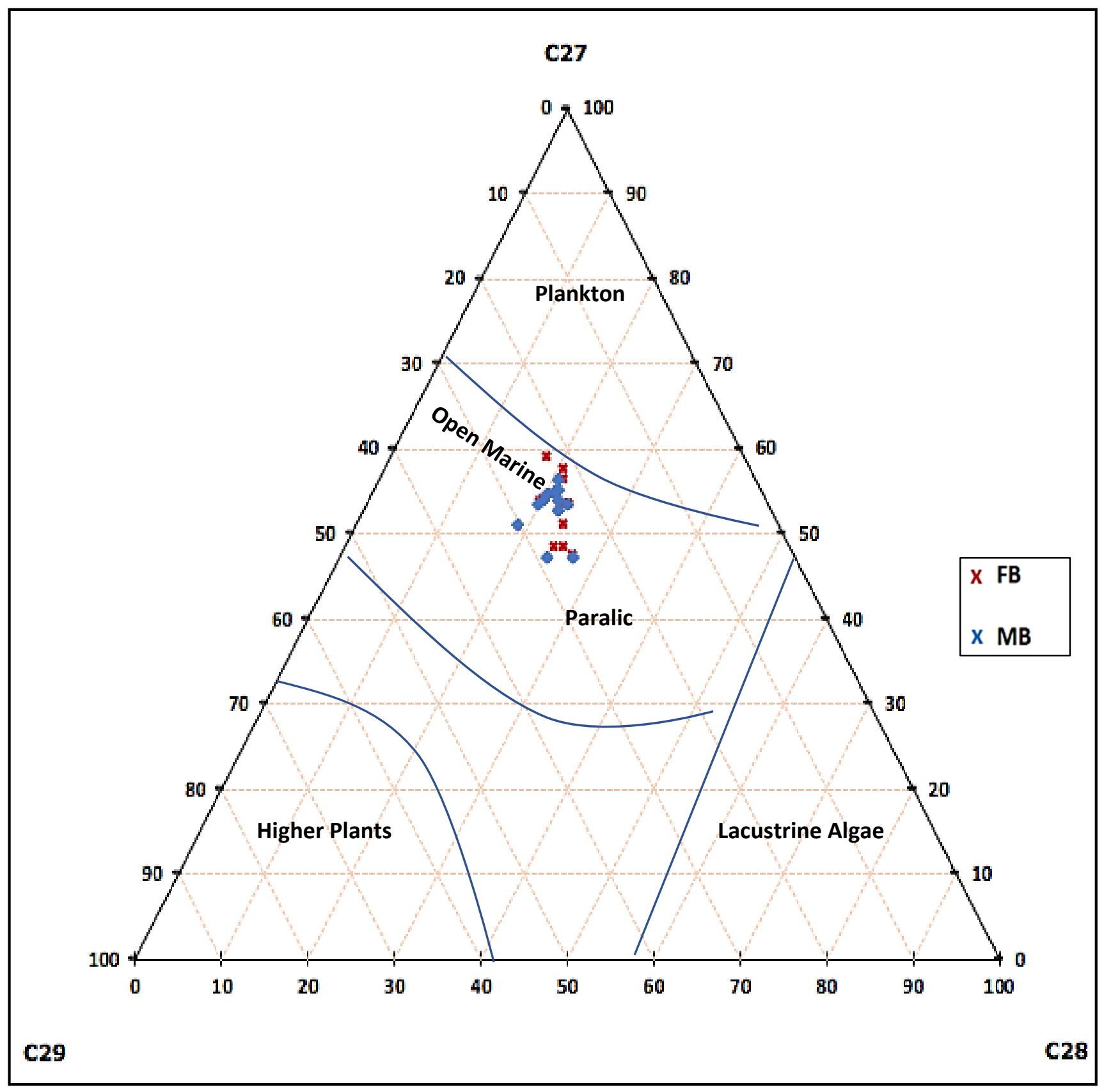


Figure 11
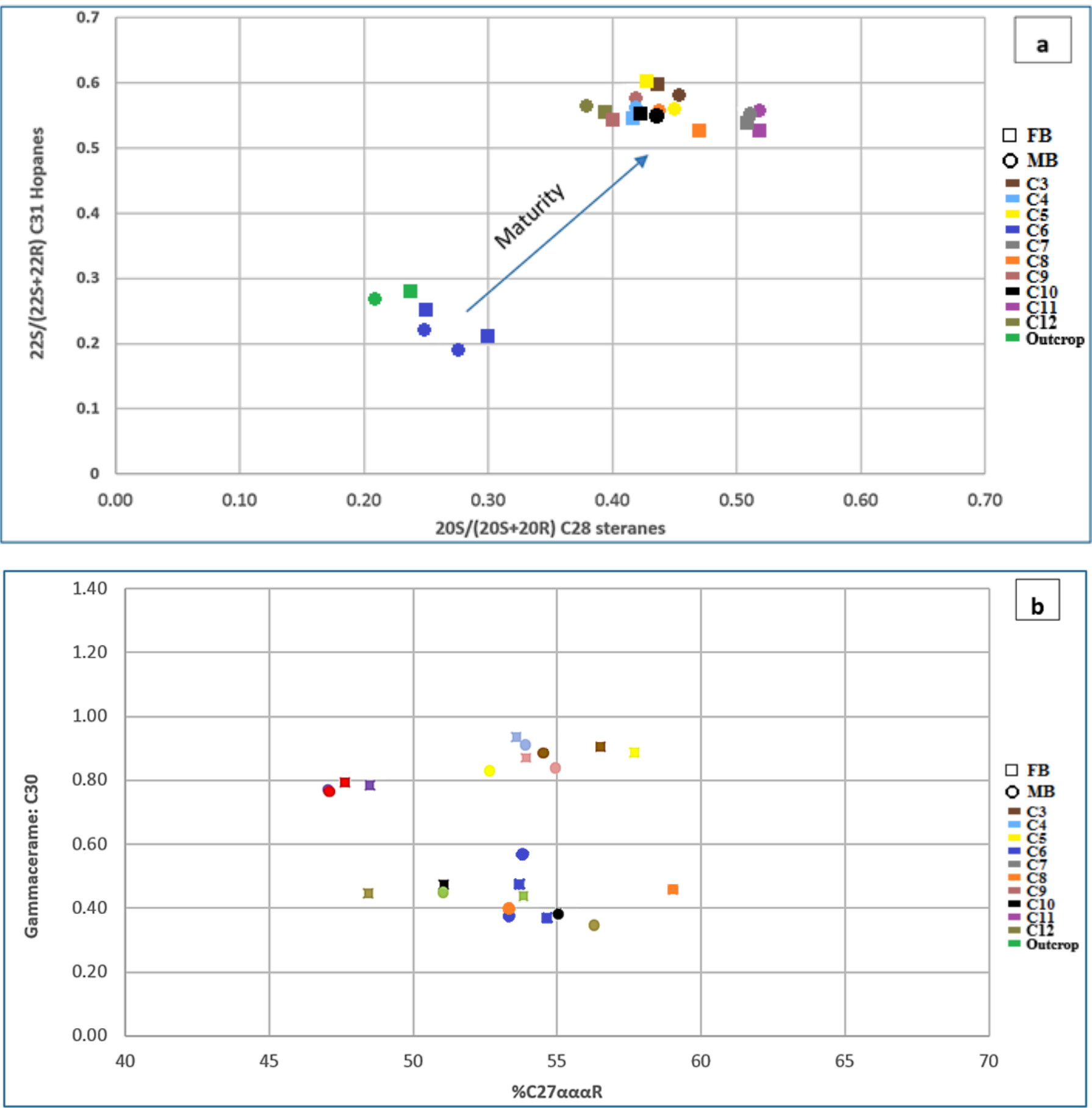
Figure 12

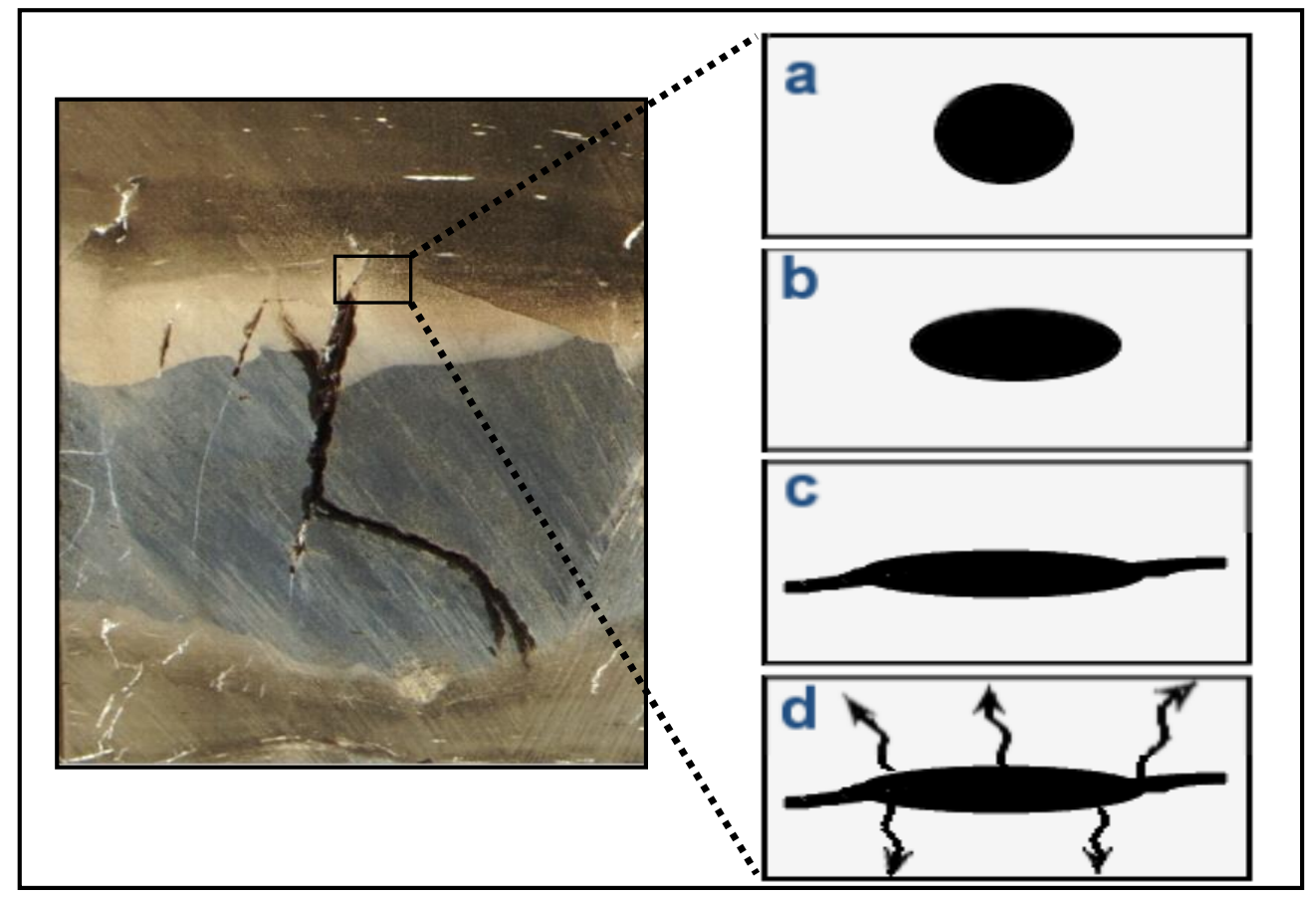

Figure 13

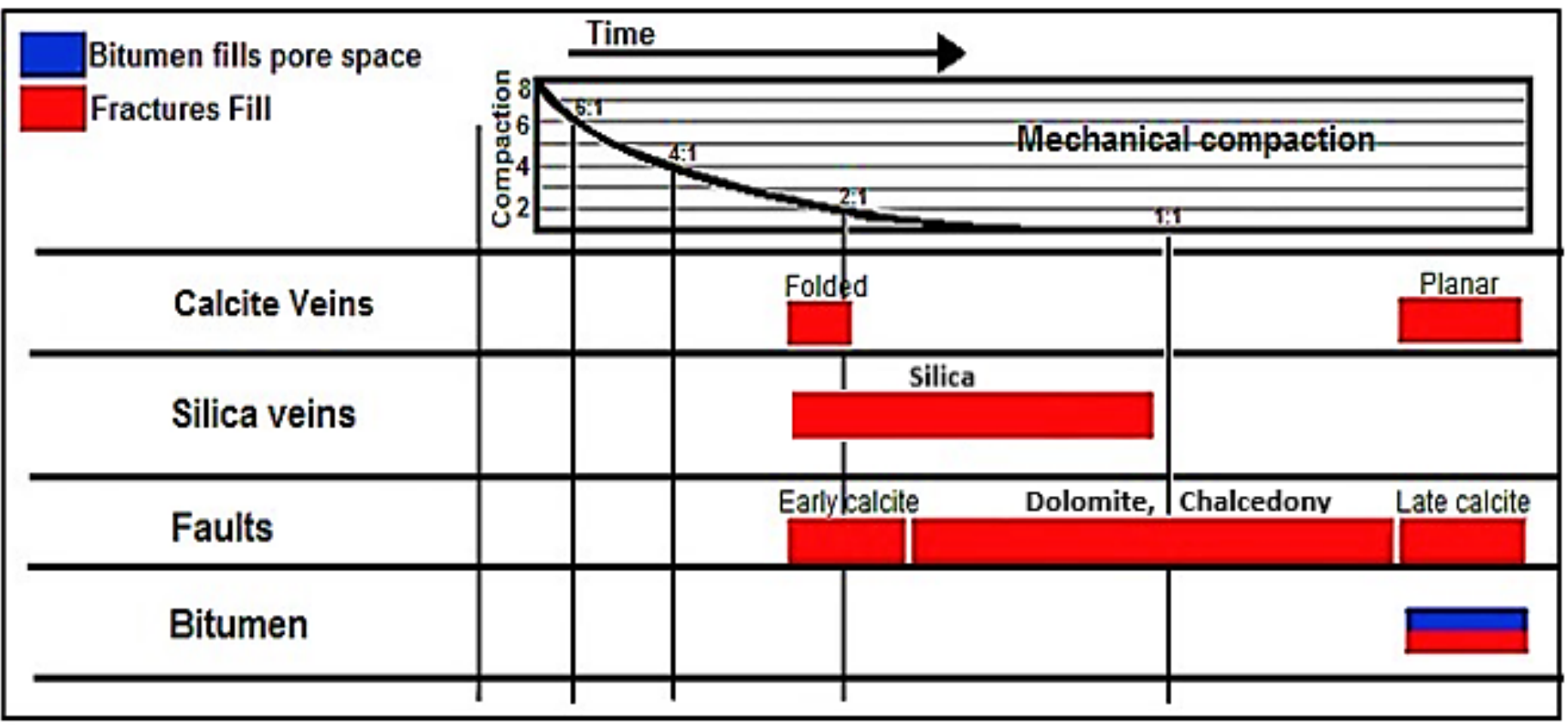


Click here to access/download supplementary material (not datasets) Supplementary data.docx 